\title{
Characterization of biogenic primary and secondary organic aerosols in the marine atmosphere over the East China Sea
}

\author{
Mingjie Kang ${ }^{1,2,3}$, Pingqing Fu ${ }^{1,2,4}$, Kimitaka Kawamura ${ }^{5}$, Fan Yang ${ }^{2}$, Hongliang Zhang ${ }^{6}$, Zhengchen Zang ${ }^{7}$, \\ Hong Ren ${ }^{2,8}$, Lujie Ren ${ }^{1}$, Ye Zhao ${ }^{3}$, Yele Sun ${ }^{2,8}$, and Zifa Wang ${ }^{2,8}$ \\ ${ }^{1}$ Institute of Surface-Earth System Science, Tianjin University, Tianjin 300072, China \\ ${ }^{2}$ State Key Laboratory of Atmospheric Boundary Layer Physics and Atmospheric Chemistry, Institute of Atmospheric \\ Physics, Chinese Academy of Sciences, Beijing 100029, China \\ ${ }^{3}$ State Key Laboratory of Water Environment Simulation, School of Environment, Beijing Normal University, \\ Beijing 100875, China \\ ${ }^{4}$ Collaborative Innovation Center on Forecast and Evaluation of Meteorological Disasters, Nanjing University \\ of Information Science \& Technology, Nanjing 210044, China \\ ${ }^{5}$ Chubu Institute for Advanced Studies, Chubu University, Kasugai 487-8501, Japan \\ ${ }^{6}$ Department of Civil and Environmental Engineering, Louisiana State University, Baton Rouge, LA 70803, USA \\ ${ }^{7}$ Department of Oceanography and Coastal Sciences, Louisiana State University, Baton Rouge, LA 70803, USA \\ ${ }^{8}$ College of Earth and Planetary Sciences, University of Chinese Academy of Sciences, Beijing 100049, China
}

Correspondence: Pingqing Fu (fupingqing@tju.edu.cn)

Received: 24 March 2018 - Discussion started: 24 April 2018

Revised: 12 August 2018 - Accepted: 4 September 2018 - Published: 2 October 2018

\begin{abstract}
Molecular composition and abundance of sugars and secondary organic aerosols (SOA) from biogenic sources over the East China Sea were investigated based on gas chromatography-mass spectrometry. Biogenic SOA tracers and sugars exhibit higher levels in the samples affected by continental air masses, demonstrating the terrestrial outflows of organic matter to the East China Sea. Glucose was the dominant sugar species $\left(0.31-209,18.8 \mathrm{ng} \mathrm{m}^{-3}\right)$, followed by mannitol - a fungal spore tracer. All sugar compounds show generally higher average concentrations in the nighttime than in the daytime. 3-Methyl-1,2,3butanetricarboxylic acid, one higher generation photooxidation tracer of monoterpene SOA, was found to be the most abundant species among measured biogenic SOA markers, suggesting the input of aged organic aerosols through longrange transport. Fungal-spore-derived organic carbon (OC) was the biggest contributor to total OC $(0.03 \%-19.8 \%$, $3.1 \%$ ), followed by sesquiterpene-derived secondary $\mathrm{OC}$ (SOC), biomass-burning-derived OC, and monoterpene- and isoprene-derived SOC. Larger carbon percentages of biogenic primary OCs and SOCs in total OC presented in the terrestrially influenced aerosols indicate significant contribu-
\end{abstract}

tions of continental aerosols through long-range transport. Positive matrix factorization results illustrate that the secondary nitrate and biogenic SOA, biomass burning, and fungal spores were the main sources of $\mathrm{OC}$ in marine aerosols over the East China Sea, again highlighting the importance of the Asian continent as a natural emitter of biogenic organic aerosols together with anthropogenic aerosols over the coastal marine atmosphere.

\section{Introduction}

Oceans cover more than $70 \%$ of the Earth's surface and marine aerosols contribute significantly to the global aerosol load (O'Dowd et al., 2004), playing an important role in the albedo, atmospheric processes, atmospheric chemistry, climate, and biogeochemical cycling of nutrients (O'Dowd and de Leeuw, 2007; Shi et al., 2011). Such influences depend on the chemical composition and concentrations of marine aerosols. In recent years, significant abundances of organic matter in marine aerosol and their importance to the cloud condensation nuclei $(\mathrm{CCN})$ formation as well as their di- 
rect and indirect radiative effects have been reported (Tervahattu et al., 2002; O'Dowd et al., 2004; Facchini et al., 2008; Ovadnevaite et al., 2011a, b; Pringle et al., 2010; Bougiatioti et al., 2011; Sciare et al., 2009). However, information about marine organic aerosol remains poor owing to various emission sources, complex formation mechanisms, and limited field measurements regarding their chemical composition and concentrations (O'Dowd and de Leeuw, 2007; Cavalli et al., 2004). Therefore, it is necessary to investigate the loadings, molecular compositions, and sources of marine organic aerosols, especially in coastal and offshore regions where the land-ocean interaction is active.

In general, sources of organic compounds in marine aerosols comprise natural and anthropogenic emissions. For example, surface-active organic matter of biogenic origin in the ocean (e.g. bacteria, viruses, and detritus) can be transferred to the marine atmosphere by bubble-bursting processes (Gantt and Meskhidze, 2013; Gershey, 1983; Mochida et al., 2002; Sciare et al., 2009). Terrestrial air masses also bring plentiful organic matter derived from natural and/or anthropogenic activities to the oceanic atmosphere via longrange atmospheric transport (Zhou et al., 1990; Uematsu et al., 2010; Kumar et al., 2012; Hawkins et al., 2010; Srinivas et al., 2011; Kang et al., 2017). Sugars, important watersoluble organic constituents of atmospheric particulate matter, are substantial in both continental (Pashynska et al., 2002; Yttri et al., 2007; Fu et al., 2008; Jia and Fraser, 2011; Iinuma et al., 2007; Cong et al., 2015) and marine aerosols (Simoneit et al., 2004b; Fu et al., 2011). Due to their ubiquity and abundance, sugars can be used to elucidate sources and transport of atmospheric organic aerosols. Levoglucosan along with its two isomers, mannosan and galactosan, as the primary thermal alteration products from the pyrolysis of cellulose and hemicellulose, have been recognized as specific tracers for biomass burning (Simoneit, 2002). Trehalose is a recognized fungal carbohydrate, which can be indicative of soil dust (Fu et al., 2012; Feng and Simpson, 2007). Arabitol and mannitol are tracers for airborne fungal spores (Bauer et al., 2008). Sucrose could serve as a marker for airborne pollen grains (Pacini, 2000; Fu et al., 2012), while fructose and glucose can be emitted from plant pollen, fruits, and detritus (Pacini, 2000; Speranza et al., 1997; Baker et al., 1998). These sugar compounds have been detected in some marine aerosols and effectively used as key tracers to assess contributions of different emission sources (Simoneit et al., 2004b). Despite their importance, knowledge about molecular characterization of sugars in marine aerosols is still rare because of various sources and inconvenience of sampling.

Apart from primary sources, atmospheric volatile organic compounds (VOCs) emitted from ocean and/or continents also have significant impacts on marine aerosols. VOCs can react with oxidants, such as ozone $\left(\mathrm{O}_{3}\right)$, nitrogen oxides $\left(\mathrm{NO}_{x}\right)$, and $\mathrm{OH}$ radicals in the atmosphere, producing secondary organic aerosols (SOA) (Atkinson and Arey, 2003; Gantt and Meskhidze, 2013; Meskhidze and Nenes, 2006;
Hu et al., 2013; Claeys et al., 2004a, 2007; Jaoui et al., 2005; Hallquist et al., 2009). SOAs contribute substantially to atmospheric particulate organic matter (OM) and strongly affects the regional and global air quality, climate, and human health (Zhu et al., 2016; Chen et al., 2017). Recent studies have revealed that SOA is an important or even the dominant contributor to $\mathrm{PM}_{2.5}$ during heavy haze events in China (Cao et al., 2017). Due to poor understanding of sources and formation mechanisms of SOA, accurately measuring and modelling SOA concentrations remains a big issue (Zheng et al., 2017). It was reported that emissions of biogenic VOCs (BVOCs) were 1 order of magnitude larger than those of anthropogenic VOCs on a global scale (Guenther et al., 2006). BVOCs emitted from terrestrial vegetation include isoprene, monoterpenes, and sesquiterpenes as well as other compounds (Guenther et al., 2006; Goldstein and Galbally, 2007), which could exert large impacts on marine aerosols through continental aerosols' outflow. On the other hand, marine phytoplankton and seaweeds can release isoprene and other BVOCs as well (Yokouchi et al., 1999; Shaw et al., 2010), especially during phytoplankton blooms (Hu et al., 2013). Marine-derived SOAs by oxidation of phytoplankton-produced isoprene have been shown to remarkably influence the chemical composition of marine $\mathrm{CCN}$ and cloud droplet number, forming an indirect climatic effect (Gantt et al., 2009; Bikkina et al., 2014; Meskhidze and Nenes, 2006). In addition to isoprene, the photooxidation products of oceanic monoterpenes (e.g. $\alpha$ - and $\beta$-pinene) were established as well (Fu et al., 2011; Yassaa et al., 2008; Gantt et al., 2009). However, to date, the accurate molecular characterization and spatial distribution of biogenic SOA (BSOA) in the marine atmosphere are not well known due to their chemical complexity and process non-linearity (Chen et al., 2017). Consequently, there is currently an urgent need for studies about marine BSOA on a regional and/or global scale.

In this study, we investigated molecular compositions, abundances, and spatial distributions of sugars and BSOA tracers in marine aerosols over the East China Sea (ECS), which is located between the east coast of the Asian continent and the western North Pacific. The ECS is an oceanic region susceptible to the influence of the outflow of continental OM from natural and anthropogenic activities in the mainland. The contributions of secondary organic carbon (SOC) from isoprene, monoterpene, and sesquiterpene to the total OC were estimated. Positive matrix factorization (PMF) was also used to estimate the contributions of sources identified by biomass burning tracers (e.g. levoglucosan), primary saccharides including fungal spore and pollen tracers, BSOA tracers from oxidation of BVOCs, inorganic ions, and some other reliable source markers. 


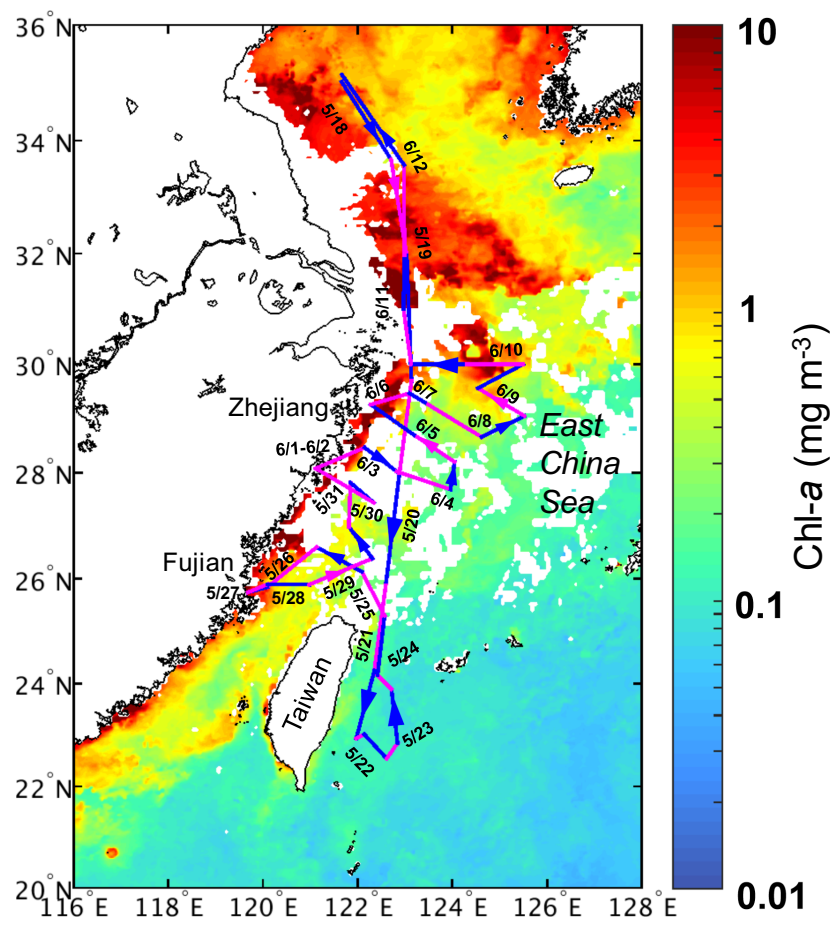

Figure 1. Cruise tracks of KEXUE-1 and spatial distribution of satellite-derived chlorophyll- $a$ concentrations (chl- $a, \mathrm{mg} \mathrm{m}^{-3}$ ) in surface seawater derived from MODIS L3 products during the sampling period in the East China Sea. The purple and blue lines represent daytime and nighttime aerosol samples, respectively.

\section{Materials and methods}

\subsection{Aerosol sampling}

Marine total suspended particles (TSP) were collected during 18 May to 12 June 2014. The sampling was performed using a high-volume air sampler (Kimoto, Japan) at an airflow rate of $0.8 \mathrm{~m}^{3} \mathrm{~min}^{-1}$ on board the KEXUE-1 research vessel during a National Natural Science Foundation of China (NSFC) sharing cruise. Figure 1 shows the cruise tracks and concentrations of chlorophyll- $a$ over the ECS. Detailed sampling information and a map of sampling sites are described elsewhere (Kang et al., 2017).

\subsection{Organic species analysis}

Filter aliquots were ultrasonically extracted for $10 \mathrm{~min}$ three times using a dichloromethane/methanol mixture $(2: 1$, $v / v)$. The solvent extracts were filtered through quartz wool packed in a Pasteur pipette and concentrated with a rotary evaporator, and then blown down to dryness with pure nitrogen gas. The extracts were reacted with $50 \mu \mathrm{L}$ of N,O-bis-(trimethylsilyl)trifluoroacetamide (BSTFA) containing $1 \%$ trimethylsilyl chloride and $10 \mu \mathrm{L}$ of pyridine at $70{ }^{\circ} \mathrm{C}$ for $3 \mathrm{~h}$ in order to convert $\mathrm{COOH}$ and $\mathrm{OH}$ to the corresponding trimethylsilyl (TMS) esters and ethers. Af- ter the reaction, $140 \mu \mathrm{L}$ internal standard $\left(\mathrm{C}_{13} n\right.$-alkane, $1.43 \mathrm{ng} \mu \mathrm{L}^{-1}$ ) was added to the derivatives before injection into gas chromatography-mass spectrometry (GC-MS).

\subsection{Gas chromatography-mass spectrometry}

Two organic species (i.e. sugars and SOA tracers) were determined on an Agilent model $7890 \mathrm{GC}$ coupled to an Agilent model 5975C mass selective detector (MSD). The GC instrument was equipped with a split/splitless injector and a DB-5ms fused silica capillary column $(30 \mathrm{~m} \times 0.25 \mathrm{~mm}$ i.d., $0.25 \mu \mathrm{m}$ film thickness) with the $\mathrm{GC}$ oven temperature programmed from $50^{\circ} \mathrm{C}(2 \mathrm{~min})$ to $120^{\circ} \mathrm{C}$ at $15^{\circ} \mathrm{C} \mathrm{min}^{-1}$, and then to $300^{\circ} \mathrm{C}$ at $5{ }^{\circ} \mathrm{C} \mathrm{min}-1$ with a final isotherm hold at $300^{\circ} \mathrm{C}$ for $16 \mathrm{~min}$. Helium was used as a carrier gas. The GC injector temperature was maintained at $280^{\circ} \mathrm{C}$. The mass spectrometer was operated in the electron ionization (EI) mode at $70 \mathrm{eV}$ and scanned in the $m / z$ range of 50 to $650 \mathrm{Da}$. Data were processed using ChemStation software. Each compound was determined through comparing mass spectra with those of authentic standards or literature data. GC-MS response factors were obtained with authentic standards or surrogate standards. Recoveries of the standards that were spiked onto pre-combusted quartz filters and measured as the samples $(n=3)$ were generally better than $80 \%$. A field blank filter was treated the same as the real samples for quality assurance. The present data were corrected with field blanks but not for recoveries.

\subsection{Positive matrix factorization (PMF) analysis}

To further investigate the potential sources of marine organic aerosols, positive matrix factorization (PMF) analysis is used in this study. For this analysis, the measured ambient concentrations less than or equal to the method detection limit (MDL) were replaced by MDL/2, and associated uncertainties were $(5 / 6) \times$ MDL. For the concentrations greater than the MDL, the calculation of uncertainty is based on the following equation:

uncertainty $=\sqrt{(\text { error fraction } \times \text { concentration })^{2}+(0.5 \times \mathrm{MDL})^{2}}$,

where the error fraction is a user-provided estimation of the analytical uncertainty of the measured concentration or flux. In the present study, the error fraction was set as 0.2 for all species for receptor-oriented source apportionment analyses (Han et al., 2017).

\section{Results and discussion}

Concentrations of sugars and biogenic SOA tracers in marine aerosols over the ECS are presented in Table 1. Total abundance of the quantified sugar compounds ranged from 1.8 to $950 \mathrm{ng} \mathrm{m}^{-3}$, with an average of $81.5 \mathrm{ng} \mathrm{m}^{-3}$ much 
Table 1. Concentrations $\left(\mathrm{ng} \mathrm{m}^{-3}\right)$ of saccharides and biogenic SOA tracers measured in the marine aerosols collected over the East China Sea during May to June 2014.

\begin{tabular}{|c|c|c|c|c|c|c|}
\hline \multirow[t]{2}{*}{ Compounds } & \multicolumn{2}{|c|}{ Whole period $(n=51)$} & \multicolumn{2}{|c|}{ Daytime $(n=25)$} & \multicolumn{2}{|c|}{ Nighttime $(n=26)$} \\
\hline & Mean & Range & Mean & Range & Mean & Range \\
\hline \multicolumn{7}{|c|}{ Anhydrosugars } \\
\hline Galactosan & 0.59 & $0.02-3.9$ & 0.56 & $0.04-3.6$ & 0.62 & $0.02-3.9$ \\
\hline Mannosan & 1.4 & $0.06-10.2$ & 1.2 & $0.08-5.2$ & 1.6 & $0.06-10.2$ \\
\hline Levoglucosan & 7.3 & $0.09-64.3$ & 6.1 & $0.09-41.2$ & 8.4 & $0.10-64.3$ \\
\hline \multicolumn{7}{|c|}{ Sugar alcohols } \\
\hline Erythritol & 1.3 & n.d. ${ }^{\mathrm{a}}-16.9$ & 0.87 & $0.02-4.60$ & 1.6 & n.d. -16.9 \\
\hline Arabitol & 5.1 & $0.02-51.0$ & 4.5 & $0.06-26.7$ & 5.7 & $0.02-51.0$ \\
\hline Mannitol & 16.3 & $0.03-169$ & 14.1 & $0.08-81.3$ & 18.4 & $0.03-169$ \\
\hline Inositol & 0.57 & $0.01-7.7$ & 0.47 & $0.01-2.8$ & 0.67 & $0.01-7.7$ \\
\hline \multicolumn{7}{|c|}{ Sugars } \\
\hline Fructose & 9.1 & $0.09-106$ & 8.1 & $0.09-56.5$ & 10.2 & $0.32-106$ \\
\hline Glucose & 18.8 & $0.31-209$ & 17.8 & $0.31-106$ & 19.7 & $0.47-209$ \\
\hline Sucrose & 11.7 & $0.09-216$ & 9.7 & $0.14-136$ & 13.5 & $0.09-216$ \\
\hline Trehalose & 9.4 & $0.08-96.0$ & 9.1 & $0.08-60.7$ & 9.7 & $0.10-96.0$ \\
\hline Total measured saccharides & 81.5 & $1.8-950$ & 72.6 & $1.0-525$ & 90.1 & $1.8-950$ \\
\hline \multicolumn{7}{|c|}{ Isoprene SOA tracers } \\
\hline 2-Methylthreitol & 1.5 & $0.01-12.7$ & 1.2 & $0.04-5.2$ & 1.9 & $0.01-12.7$ \\
\hline 2-Methylerythritol & 3.2 & $0.02-29.1$ & 2.5 & $0.08-11.8$ & 3.9 & $0.02-29.1$ \\
\hline Sum of 2-methyltetrols & 4.8 & $0.03-41.9$ & 3.8 & $0.11-17.0$ & 5.7 & $0.03-41.9$ \\
\hline 2-Methylglyceric acid (2-MGA) & 1.4 & $0.09-8.3$ & 1.2 & $0.20-3.6$ & 1.6 & $0.09-8.33$ \\
\hline$C_{5}$-Alkene triols ${ }^{\mathrm{b}}$ & 2.2 & $0.03-14.6$ & 2.1 & $0.06-14.6$ & 2.3 & $0.03-13.8$ \\
\hline Subtotal & 8.4 & $0.15-64.0$ & 7.1 & $0.42-35.2$ & 9.6 & $0.15-64.0$ \\
\hline \multicolumn{7}{|c|}{$\alpha / \beta$-pinene (monoterpene) SOA tracers } \\
\hline 3-Hydroxyglutaric acid (3-HGA) & 2.2 & $0.03-14.1$ & 2.3 & $0.08-14.1$ & 2.1 & $0.03-7.7$ \\
\hline Pinonic acid (PNA) & 0.47 & $0.02-1.6$ & 0.49 & $0.06-1.6$ & 0.46 & $0.02-1.6$ \\
\hline Pinic acid (PA) & 3.4 & $0.16-14.9$ & 3.4 & $0.28-14.9$ & 3.3 & $0.16-13.6$ \\
\hline MBTCA & 5.6 & n.d. -56.9 & 6.8 & n.d. -56.9 & 4.5 & n.d. -24.5 \\
\hline Subtotal & 11.6 & $0.26-87.2$ & 13.0 & $0.45-87.2$ & 10.3 & $0.26-43.7$ \\
\hline \multicolumn{7}{|c|}{$\beta$-caryophyllene (sesquiterpene) SOA tracers } \\
\hline$\beta$-Caryophyllinic acid & 2.9 & $0.16-17.2$ & 3.5 & $0.17-17.2$ & 2.3 & $0.16-9.6$ \\
\hline Total measured biogenic SOA tracers & 22.9 & $1.1-135$ & 23.6 & $1.4-135$ & 22.2 & $1.1-115$ \\
\hline
\end{tabular}

lower than those in the urban atmosphere in China (Wang et al., 2006), and the nighttime aerosols contained more sugars (average $90.1 \mathrm{ng} \mathrm{m}^{-3}$ ) than the daytime ones $\left(72.6 \mathrm{ng} \mathrm{m}^{-3}\right.$ ). Individual sugar compounds also showed higher nighttime concentrations, but still lower than those in urban aerosols (Wang et al., 2011). The total biogenic SOA tracers were in the range of $1.1-135 \mathrm{ng} \mathrm{m}^{-3}$ (average $22.9 \mathrm{ng} \mathrm{m}^{-3}$ ) with lower nighttime abundance $\left(22.2 \mathrm{ng} \mathrm{m}^{-3}\right)$ than in the daytime $\left(23.6 \mathrm{ng} \mathrm{m}^{-3}\right)$. In contrast to monoterpene and sesquiterpene
SOA tracers, the isoprene SOA tracers presented higher levels in the nighttime aerosols $\left(9.6 \mathrm{ng} \mathrm{m}^{-3}\right)$ than those in the daytime samples $\left(7.1 \mathrm{ng} \mathrm{m}^{-3}\right)$. Generally, higher values of these organics were observed in coastal regions compared with those far away from the mainland (Figs. 2, 4 and S1 in the Supplement), similar to the spatial pattern of lipids, PAHs, and phthalates in our previous report (Kang et al., 2017), suggesting the impact from the outflow of continental $\mathrm{OM}$ on the basis of back trajectory analysis (Figs. S2-S6). 


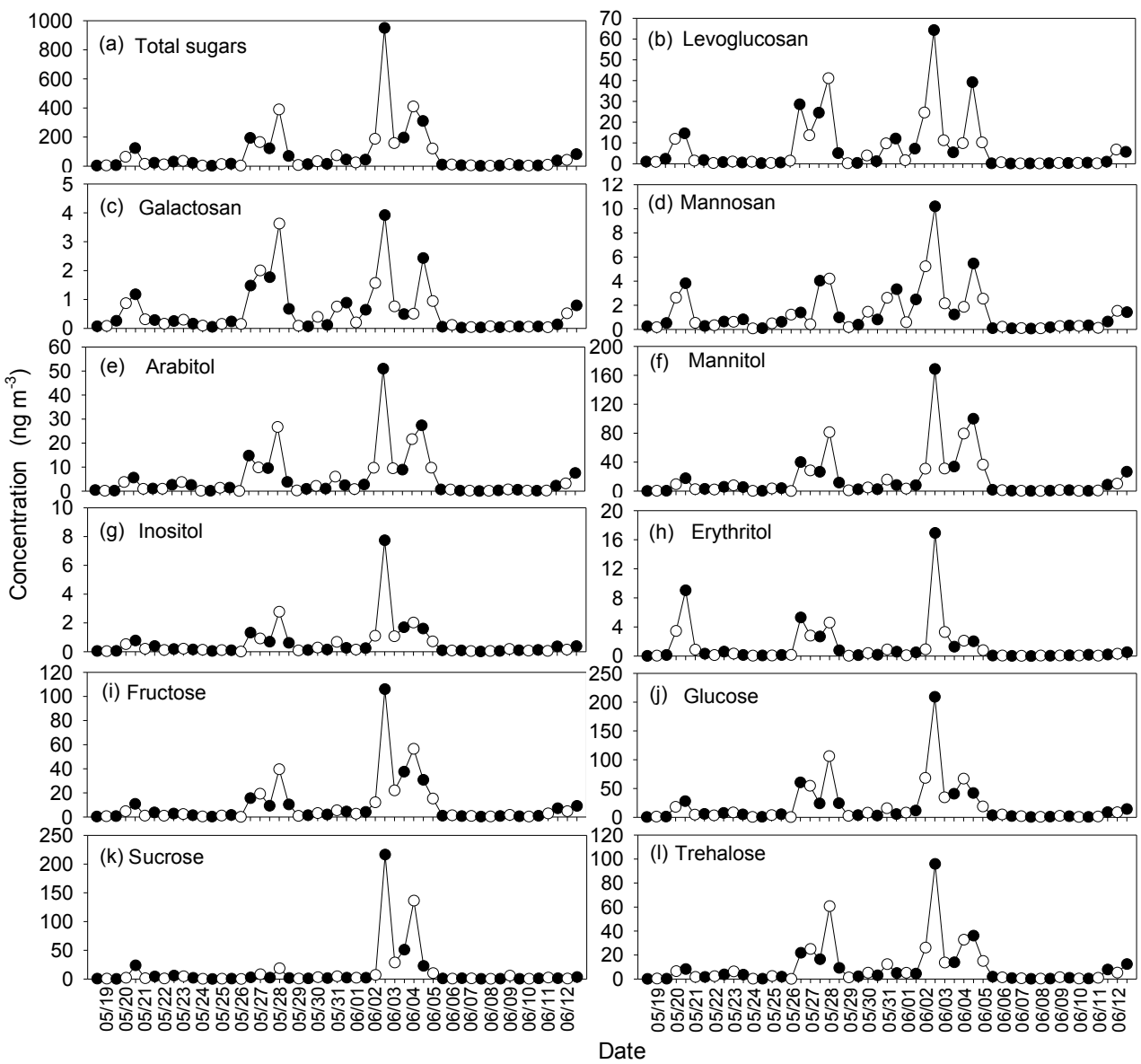

Figure 2. Temporal variations in sugar compounds in marine aerosols collected over the East China Sea. The open and shaded circles represent daytime and nighttime values, respectively.

\subsection{Sugars and sugar alcohols}

Sugars, a major class of water-soluble organic constituents in the atmosphere, have been reported to be ubiquitous in marine aerosols (Fu et al., 2011; Chen et al., 2013; Simoneit et al., 2004b; Burshtein et al., 2011). Most of them can serve as tracers of biological primary aerosol particles and biomass burning (Simoneit, 2002; Bauer et al., 2008). A total of 11 sugar compounds including anhydrosugars (levoglucosan, galactosan, and mannosan), sugars (fructose, glucose, sucrose, and trehalose), and sugar alcohols (erythritol, arabitol, mannitol, and inositol) were measured in marine aerosols collected over the ECS. The concentrations of sugars are shown in Table 1 and Fig. 2. Glucose $\left(0.31-209\right.$, mean $\left.18.8 \mathrm{ng} \mathrm{m}^{-3}\right)$ and mannitol (0.03-169, $16.3 \mathrm{ng} \mathrm{m}^{-3}$ ) were the dominant species, followed by sucrose $\left(0.09-216,11.7 \mathrm{ng} \mathrm{m}^{-3}\right)$, trehalose $\left(0.08-96.0,9.4 \mathrm{ng} \mathrm{m}^{-3}\right)$, fructose $\left(0.09-106,9.1 \mathrm{ng} \mathrm{m}^{-3}\right)$, and levoglucosan $(0.09-$ 64.3, $7.3 \mathrm{ng} \mathrm{m}^{-3}$ ) (Fig. 3). Chen et al. (2013) also reported that glucose and mannitol are the major sugar compounds detected in marine aerosols collected at Chichi-Jima Island during spring and summer. Moreover, nighttime concentrations of all sugars were generally higher than the daytime ones, likely due to the lower height of the planetary boundary layer (PBL) and the land breeze carrying plentiful terrestrial $\mathrm{OM}$ at night.

Figure 2 presents the temporal variations in sugar compounds determined in the marine aerosol samples collected over the ECS. The concentrations of total sugars were characterized by higher levels in the regions close to the continent and/or influenced by land air masses, indicating the substantial influence of continental outflow compared to marine air over the pelagic ocean.

\subsubsection{Anhydrosugars}

Levoglucosan, a thermal degradation production of cellulose (Simoneit, 2002) and a specific indicator for biomass burning (Simoneit et al., 1999), can largely modify the chemical composition of atmospheric aerosols on a regional to global scale. Due to its water solubility, levoglucosan contributes to watersoluble organic carbon in aerosols, significantly enhancing the hygroscopic properties of atmospheric aerosols (Mochida 


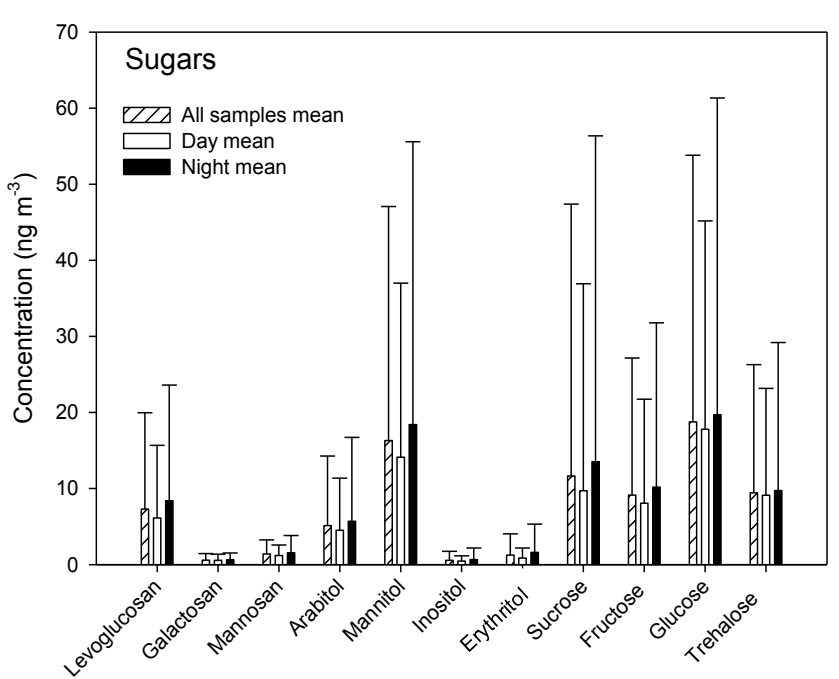

Figure 3. Average concentrations of sugars detected in marine aerosols over the East China Sea.

and Kawamura, 2004). The abundance of levoglucosan detected in the present study $\left(0.09-41.2 \mathrm{ng} \mathrm{m}^{-3}\right.$, mean 6.1 for day and $0.10-64.3 \mathrm{ng} \mathrm{m}^{-3}$, mean $8.4 \mathrm{ng} \mathrm{m}^{-3}$ for night) was not the highest among measured sugar species (Fig. 3 and Table 1). The average concentration of levoglucosan is close to that reported at Gosan, Jeju Island, in summer (mean $8.0 \mathrm{ng} \mathrm{m}^{-3}$ ) (Fu et al., 2012). During the whole sampling period, higher concentrations of levoglucosan were found in the samples under the effect of continental air masses based on 5-day backward trajectories (Figs. S2-S6), consistent with our previous report about lipids, PAHs, and phthalates (Kang et al., 2017). Mannosan and galactosan, isomers of levoglucosan, are produced by pyrolysis of cellulose and hemicellulose and can also act as biomass burning tracers (Fabbri et al., 2009; Simoneit, 2002). Mannosan and galactosan were detected in the samples with similar variation trends to levoglucosan (Table 1 and Fig. 2), further indicating the strong impact of continental biomass burning activities on the marine atmosphere. As shown in Table 1 and Fig. 3, the nighttime average concentrations of all three anhydrosugars were higher than the daytime ones, probably attributable to enhanced biomass combustion and the lower height of the PBL as well as the land breeze during the night.

In addition, hardwood tends to contain higher levels of cellulose than hemicellulose; therefore the mass concentration ratios of levoglucosan to mannosan (L/ M) can be utilized as a diagnostic parameter for diverse biomass burning substrates (Zhu et al., 2015). Previous studies found that L / M ratios from softwood are in a range of 3-10 and those from hardwood are 15-25, while the ratios from crop residues are even higher (25-40) (Zhu et al., 2015). In this study, the $\mathrm{L} / \mathrm{M}$ ratios range from 0.71 to 32 with an average of 4.2 , and higher values were observed in the terrestrially influenced aerosols, especially in the coastal areas near Fujian Province
(Fig. S7). The lower L / M ratios in our study (average 4.2) suggest that the aerosols were mainly associated with the burning of softwood, consistent with the lower L / M ratios (2.1-4.8) observed on Okinawa Island in May-June (Zhu et al., 2015) and Mt Fuji (4.6-7.6, mean 5.5) (Fu et al., 2014). It is worth noting that a couple of samples near Fujian Province in Southeast China were characterized by a higher L / M ratio (>20) (Fig. S7), agreeing well with the values of straw burning smokes (Chen et al., 2013). Zhu et al. (2015) also reported combustion of agricultural residues, peat, and wood could contribute to high $\mathrm{L} / \mathrm{M}$ ratios. Therefore, these higher values probably indicate emissions from terrestrial burning of straw residues, which could affect the chemical components of aerosols in the western North Pacific via long-range atmospheric transport as confirmed by backward trajectories (Fig. S5).

\subsubsection{Sugar alcohols}

Sugar alcohols detected in these samples consist of arabitol, mannitol, inositol, and erythritol, which had similar temporal patterns (Fig. 2e-h). Higher abundances of sugar alcohols observed in the terrestrially influenced aerosol samples suggest a significant contribution from terrestrial sources (Figs. S2-S6), while the marine fungi and algae, which can also release fungal spores into the marine atmosphere via bubble bursting, contribute little to the sugar alcohols in the coastal aerosols. Obviously, mannitol and arabitol were the most abundant sugar alcohols detected in the present study (Fig. 3 and Table 1), ranging from 0.03 to $169 \mathrm{ng} \mathrm{m}^{-3}$ $\left(16.3 \mathrm{ng} \mathrm{m}^{-3}\right)$ and $0.02-51.0 \mathrm{ng} \mathrm{m}^{-3}\left(5.1 \mathrm{ng} \mathrm{m}^{-3}\right)$, respectively. A strong positive correlation between arabitol and mannitol was found in marine aerosols $(p<0.001, r=$ 0.996, $N=51$ ), suggesting a similar origin. Mannitol and arabitol are very common in fungi, and are the most frequently occurring sugar alcohols in plants (Burshtein et al., 2011), which can be utilized to assess the contribution of fungal spores to the aerosol OC (Bauer et al., 2008). For instance, mannitol is particularly abundant in algae (Burshtein et al., 2011). The peak concentrations of sugar alcohols were found in the nighttime samples, which can be attributed to the increased activities of yeasts and fungi at night (Graham et al., 2003). Moreover, the maxima concentrations of these sugar polyols, especially arabitol and mannitol, were observed in offshore regions in early summer (June) (Fig. 2eh), likely due to the more active microbial activities resulting from warmer temperature in June and more biota in coastal regions (Fig. 1).

\subsubsection{Sugars}

Glucose, fructose, sucrose, and trehalose are the primary saccharides measured in marine aerosols over the ECS. Glucose was the dominant sugar compound $\left(0.31-209,18.8 \mathrm{ng} \mathrm{m}^{-3}\right)$, followed by sucrose $\left(0.09-216,11.7 \mathrm{ng} \mathrm{m}^{-3}\right.$ ) (Figs. 2i-1 
and 3). Glucose and fructose originate from plant materials, such as pollen, fruits, and their fragments ( $\mathrm{Fu}$ et al., 2012; Graham et al., 2003). Both glucose and fructose presented higher levels in the coastal areas, demonstrating a great contribution from terrestrial vegetation. Medeiros and Simoneit (2007) reported that a high abundance of glucose associated with lower molecular weight fatty acids (mainly $\mathrm{C}_{16}$ ) was attributed to the spring bloom of algae. In our study, glucose correlated well with measured $\mathrm{C}_{16: 0}$ fatty acid ( $p=0.001, r=0.46, N=51$ ), which were mainly emitted from the ocean surface via sea spray (Kang et al., 2017), suggesting that marine sources also contributed to the particulate glucose in the oceanic atmosphere. It was noted that fructose had a strong correlation with glucose $(p<0.001$, $r=0.94, N=51$ ), indicating they share similar sources. Sucrose, as a predominant sugar species in the phloem of plants as well as developing flower buds, is reported to be the richest and dominant component of airborne pollen grains (Graham et al., 2003). The high abundance of sucrose along with fructose and glucose observed in our study implies a large emission of airborne pollen grains into the marine atmosphere over the ECS. Significantly, the concentrations of glucose, fructose, and sucrose were highest at the beginning of June in early summer (Fig. 2i-1), probably attributable to an enhanced pollen emission, because pollen counts tend to be highest in late spring/early summer in temperate zones (Graham et al., 2003). Such peak concentrations in early June are in accord with a previous study by Pashynska et al. (2002). Trehalose, a fungal metabolite, is present in a variety of microorganisms (fungi, bacteria, yeast, and algae) and a few higher plants as well as invertebrates (Medeiros et al., 2006a). Thus, trehalose can be used as a microbial biomarker and stress protectant. Furthermore, trehalose was reported to be the most abundant sugar in soil (Rogge et al., 2007; Medeiros et al., 2006b; Jia and Fraser, 2011); thus the enrichment of trehalose in aerosols can be indicative of soil resuspension and unpaved road dust (Simoneit et al., 2004a; Fu et al., 2012). The trehalose in our study was positively correlated with non-sea-salt calcium $\left(\mathrm{nss}-\mathrm{Ca}^{2+}\right)(p<0.01$, $r=0.43, N=51$ ), the best tracer for soil dust (Virkkula et al., 2006), suggesting that the atmospheric trehalose over the ECS was mainly derived from the resuspension of soil particles. The higher abundance of trehalose in coastal regions (Fig. 21) may be in connection with the outflow of Asian dust primarily occurring in winter/spring (Fu et al., 2012) and inland soil resuspension/dust aerosols.

\subsection{Secondary organic aerosols}

The sum of all SOA tracers ranged from 1.1 to $135 \mathrm{ng} \mathrm{m}^{-3}$ $\left(22.9 \mathrm{ng} \mathrm{m}^{-3}\right)$, which was higher than a previous report of marine aerosols $\left(0.19-27,6.6 \mathrm{ng} \mathrm{m}^{-3}\right.$ ) (Fu et al., 2011), but much lower than in the continental sites (Fu et al., 2010; Ding et al., 2014). These differences suggest that the major source of SOA tracers over the ECS is of terrestrial origin. Specifi- cally, the total concentrations of detected isoprene SOA tracers range from 0.15 to $64.0 \mathrm{ng} \mathrm{m}^{-3}\left(8.4 \mathrm{ng} \mathrm{m}^{-3}\right)$, comparable to those reported in marine aerosols (mean $8.5 \mathrm{ng} \mathrm{m}^{-3}$ ) (Hu et al., 2013), but are lower than those of urban aerosols (Ren et al., 2017; Ding et al., 2014). Total monoterpene SOA tracers in the range of $0.26-87.2 \mathrm{ng} \mathrm{m}^{-3}\left(11.6 \mathrm{ng} \mathrm{m}^{-3}\right)$ were lower than those in urban aerosols as well (Ren et al., 2017); total sesquiterpene SOA tracers ranged between 0.16 and $17.2 \mathrm{ng} \mathrm{m}^{-3}\left(2.9 \mathrm{ng} \mathrm{m}^{-3}\right)$. Such phenomena that BSOA derived from monoterpenes is more abundant than that from isoprene were also reported in Chinese urban areas (Ren et al., 2017). On the whole, biogenic SOA tracers exhibited higher loadings in the coastal areas than those remote sampling sites, further indicating that long-range atmospheric transport of terrestrial aerosols has significant influence on the chemical composition and abundance of SOA over oceans. Marine VOC spatial distributions are expected to be linked to the distributions of photosynthetic pigments in seawater, such as chlorophyll- $a$ (Ooki et al., 2015). The higher concentrations of chlorophyll- $a$ in the coastal regions (Fig. 1) stand for higher biological activities and more emission of VOCs, which agrees well with higher SOA tracers over the coastal waters. Such spatial variations in biogenic SOA tracers are in agreement with a previous report about marine organic aerosols collected during a round-the-world cruise (Fu et al., 2011).

\subsubsection{Isoprene SOA tracers}

Isoprene is a reactive biogenic hydrocarbon and primarily originates from terrestrial photosynthetic vegetation (e.g. trees and plants). Marine phytoplankton and seaweed can also emit isoprene (Yokouchi et al., 1999; Shaw et al., 2010). Moreover, bacteria produce isoprene as well, and the bacterial isoprene production is temperature-dependent (Kurihara et al., 2010). In spite of much lower emission strength in the ocean region, more recent research has suggested that the oceanic sources of isoprene significantly impact atmospheric chemistry and cloud microphysical properties in the remote marine boundary layer because of its high reactivity (about 1-2 h lifetime) (Hackenberg et al., 2017).

Six isoprene SOA tracers, including 2-methylglyceric acid, three $\mathrm{C}_{5}$-alkene triols, and two 2-methyltetrols (2methylthreitol and 2-methylerythritol), were identified in the marine aerosols over the ECS. Isoprene SOA tracers showed diurnal variations, with higher average concentrations at night (Figs. 4a-c, 5, S8), consistent with the report by $\mathrm{Fu}$ et al. (2010). The higher abundance during the night can be explained by the enhanced gas-particle partition at cooler temperatures during the nighttime and/or increased input of continent-originated isoprene SOA into the oceanic atmosphere via land-sea breeze circulations at night. However, a $t$ test showed that the difference between daytime and nighttime concentrations for 2-methyltetrols, $\mathrm{C}_{5}$-alkene triols, and 2-MGA was not that significant $(p>0.05)$. As ex- 


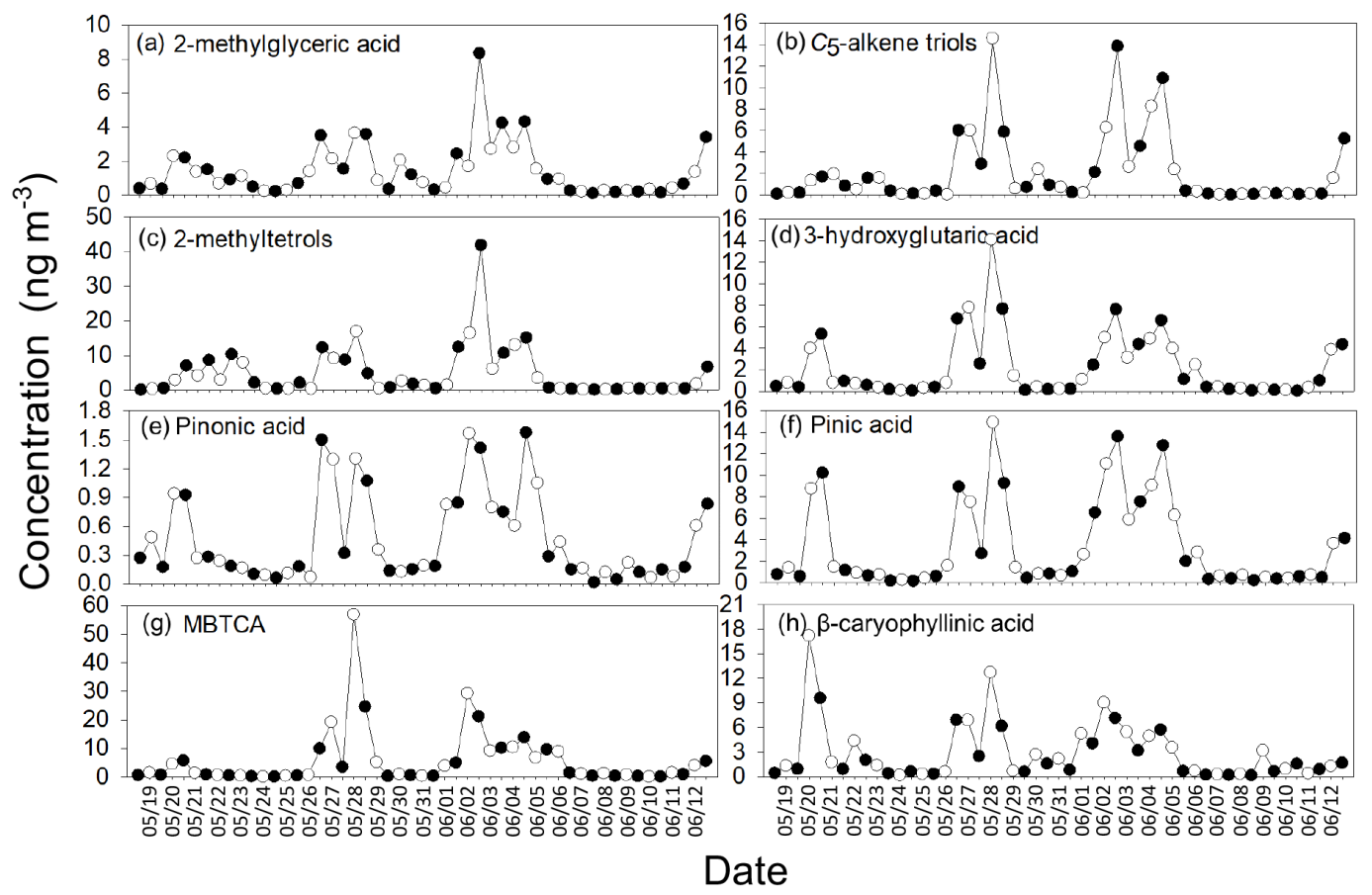

Figure 4. Temporal variations in biogenic SOA tracers detected in marine aerosols over the East China Sea during May to June 2014. The open and shaded circles represent daytime and nighttime values, respectively.

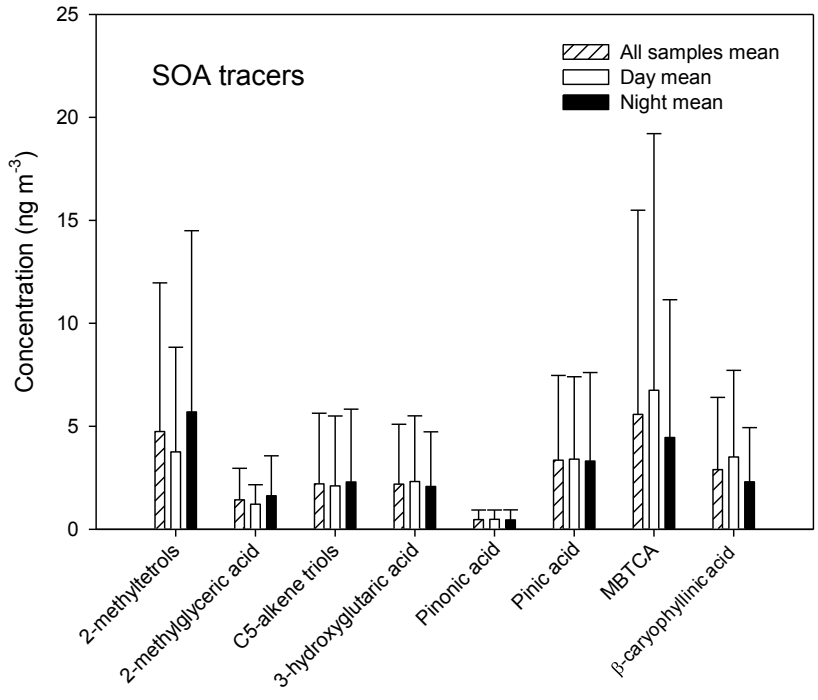

Figure 5. Average concentrations of SOA tracers detected in marine aerosols over the East China Sea.

pected, much higher concentrations of isoprene tracers were observed in coastal regions, where continental outflows exert larger effects from spring to early summer. For the remote ocean, terrestrial sources have weak impacts because of the short atmospheric lifetime of isoprene and the dilution effects during long-range atmospheric transport. In addition to the effect of continental outflow, more nutrients in the coastal and estuarine regions could be another factor responsible for the higher levels of isoprene SOA tracers compared to the pelagic areas. Because nutrient-rich surface water can promote the development of phytoplankton blooms, it increases chlorophyll- $a$ concentrations. Chlorophyll- $a$ is a measure of phytoplankton, or algal, biomass (Quinn et al., 2014) and currently most widely used proxy for predicting isoprene concentrations in water (Hackenberg et al., 2017). Numerous studies reported the positive relationship between isoprene emission and chlorophyll- $a$ in the surface seawater (Hackenberg et al., 2017; Zhu et al., 2016). In the present study, the temporal and spatial distributions of chlorophyll- $a$ at the ECS surface during the whole sampling period are characterized by higher coastal levels, such as waters near Zhejiang and Fujian provinces, but lower abundance in eastern Taiwan and the remote sea (Fig. 1). Thus, high chlorophyll- $a$ waters in coastal locations mean more isoprene emissions than remote open waters. However, the isoprene in the remote ocean may mainly originate in situ from biological production by marine biota at the ocean surface.

The low- $\mathrm{NO}_{x}$ products 2-methyltetrols with mass concentrations ranging from 0.03 to $41.9 \mathrm{ng} \mathrm{m}^{-3}\left(4.8 \mathrm{ng} \mathrm{m}^{-3}\right)$ were the major species among the isoprene SOA tracers, in line with an earlier report about summer aerosols in China (Ding et al., 2014). In particular, concentration ranges of 2methyltetrols were $0.11-17.0 \mathrm{ng} \mathrm{m}^{-3}\left(3.8 \mathrm{ng} \mathrm{m}^{-3}\right)$ during the daytime and $0.03-41.9 \mathrm{ng} \mathrm{m}^{-3}\left(5.7 \mathrm{ng} \mathrm{m}^{-3}\right)$ at night, with 2methylerythritol being about 2.1-fold more abundant than 2 - 
methylthreitol. This ratio is similar to the ratios calculated in previous studies (Fu et al., 2010; Ion et al., 2005; Cahill et al., 2006). The atmospheric levels of 2-methyltetrols are comparable to those reported in marine aerosols collected during a round-the-world cruise $\left(0.07-15,2.4 \mathrm{ng} \mathrm{m}^{-3}\right)(\mathrm{Fu}$ et al., 2011). However, these values are small compared to those from terrestrial emissions, such as mountain (Fu et al., 2014; Cahill et al., 2006) and forest aerosols (Miyazaki et al., 2012; Fu et al., 2010; Claeys et al., 2004a). A significant positive relationship between 2-methyltetrols and levoglucosan $(p<0.001, r=0.87, N=51)$ in our study suggests that biomass burning may also generate the precursors of 2-methyltetrols followed by photochemical reactions (Xie et al., 2014). In addition, 2-methyltetrols correlated with $\mathrm{C}_{29} n$-alkane (the dominant species of terrestrial higher plant waxes) as well $(p<0.001, r=0.74, N=51)$, suggesting these organic tracers originate from higher plants or from similar source regions as well. The correlations above illustrate that terrestrial emissions (e.g. biomass burning and higher plants) contributed significantly to the levels of 2methyltetrols in the marine atmosphere.

$\mathrm{C}_{5}$-Alkene triols are formed from the photooxidation of isoprene under low-NO $\mathrm{NO}_{x}$ conditions (Surratt et al., 2006; Lin et al., 2013). They were detected in all the samples ranging from 0.03 to $14.6\left(2.2 \mathrm{ng} \mathrm{m}^{-3}\right)$, which are higher values than those reported in Arctic aerosols $\left(0.01-0.15 \mathrm{ng} \mathrm{m}^{-3}\right)$ (Fu et al., 2009) and other marine aerosols (0.002-4.6, $0.65 \mathrm{ng} \mathrm{m}^{-3}$ ) (Fu et al., 2011), but lower than the atmospheric levels of mountain aerosols (Fu et al., 2010, 2014) and subtropical urban aerosols from Hong Kong (Hu et al., 2008). Such a difference illustrates the outflow of continental aerosols, which can be confirmed by the significant positive correlations between $\mathrm{C}_{5}$-alkene triols and tracers of terrestrial emissions, such as $\mathrm{C}_{29} n$-alkanes $(p<0.001, r=0.78$, $N=51)$ and levoglucosan $(p<0.001, r=0.87, N=51)$. It was found that 2-methyltetrols correlated well with $\mathrm{C}_{5}$ alkene triols in marine aerosols over ECS $(p<0.001, r=$ $0.86, N=51$ ), suggesting a similar formation mechanism or common sources. However, the mass concentration ratios of $\mathrm{C}_{5}$-alkene triols to 2-methyltetrols showed significant variation in different sampling sites (Fig. 6a), indicating different formation pathways, consistent with a previous report (Fu et al., 2010).

Concentrations of 2-methylglyceric acid (2-MGA), formed by photooxidation of isoprene under high- $\mathrm{NO}_{x}$ $\left(\mathrm{NO}_{\mathrm{x}}=\mathrm{NO}+\mathrm{NO}_{2}\right)$ conditions (Surratt et al., 2006), were in the range of $0.09-8.3 \mathrm{ng} \mathrm{m}^{-3}\left(1.4 \mathrm{ng} \mathrm{m}^{-3}\right)$, being greatly lower than those in mountain aerosols (Cahill et al., 2006; Fu et al., 2010, 2014), implying a much stronger influence of $\mathrm{NO}_{x}$ on isoprene SOA formation in continental aerosols. 2MGA is a possible further oxidation product of methacrolein and methacrylic acid, which are two major gas-phase oxidation products of isoprene (Claeys et al., 2004b; Edney et al., 2005; Fu et al., 2009). 2-MGA was related to $\mathrm{C}_{29}$ $n$-alkanes $(p<0.001, r=0.84, N=51)$ and levoglucosan

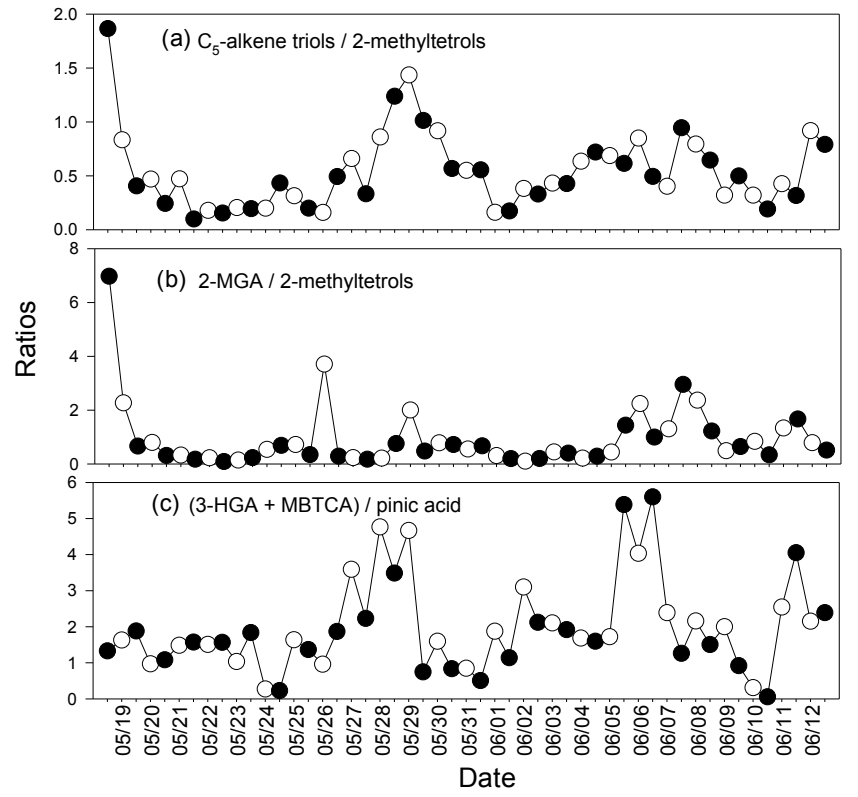

Figure 6. Temporal variations in the concentration ratios of isoprene and $\alpha / \beta$-pinene oxidation products in the marine aerosols over the East China Sea. The open and shaded circles represent daytime and nighttime samples, respectively.

( $p<0.001, r=0.81, N=51)$ as well, again suggesting a terrestrial input. These isoprene SOA tracers in marine aerosols over the ECS may stem from terrestrial higher plants and biomass burning, and then were oxidized during the transport to the oceanic atmosphere. Similar correlations between isoprene-derived SOA tracers and levoglucosan were mentioned in a previous study, which reported that biomass burning enhanced the isoprene SOA formation (Li et al., 2018). Additionally, 2-methyltetrols are higher generation products than 2-MGA (Fu et al., 2014), but the ratios of 2-MGA to 2-methyltetrols did not vary significantly with cruise track. However, a couple of high ratios were observed in the ocean-air-influenced aerosols, suggesting the importance of marine sources for fresh isoprene-derived SOAs in the atmosphere (Fig. 6b).

$\mathrm{NO}_{3}^{-}$was found to be related to 2-MGA, 2-methyltetrols, and $\mathrm{C}_{5}$-alkene triols $(p<0.001, r=0.60-0.71, N=51)$. The ratio of 2-MGA to 2-methyltetrols was found to be negatively correlated with particulate $\mathrm{NO}_{3}^{-}(p<0.05, r=-0.31$, $N=51)$. These relationships reveal that there may be a close connection between the formation of isoprene $\mathrm{SOA}$ and $\mathrm{NO}_{3}^{-}$ in the marine boundary layer.

\subsubsection{Monoterpene SOA tracers}

The detected $\alpha / \beta$-pinene oxidation products in the study consist of pinonic, pinic acids, 3-hydroxyglutaric acid (3-HGA), and 3-methyl-1,2,3-butanetricarboxylic acid (MBTCA). They are derived from the photooxidation of 
$\alpha / \beta$-pinene with $\mathrm{O}_{3}$ and $\mathrm{OH}$ radicals (Hoffmann et al., 1997; Yu et al., 1999; Glasius et al., 2000; Iinuma et al., 2004). Since monoterpenes account for around $35 \%$ of the global biogenic VOCs' emissions, these compounds have been utilized to estimate the role of monoterpene oxidation in the SOA formation (Griffin et al., 1999). Monoterpenes were chiefly emitted from needle leaf trees. In this study, monoterpene SOA tracers were found to be positively correlated to levoglucosan with $p<0.001$ ( $r$ ranges from 0.68 to 0.82 ), indicating terrestrial biomass burning made substantial contributions to the formation of monoterpenes, then were transported to the oceanic atmosphere. Generally, total monoterpene SOA tracers in our study showed a major peak in spring (Fig. S1g), in agreement with a previous study (Zhu et al., 2016). Pinonic and pinic acids, well-known tracers for $\alpha / \beta$-pinene, ranged from 0.02 to $1.6 \mathrm{ng} \mathrm{m}^{-3}\left(0.47 \mathrm{ng} \mathrm{m}^{-3}\right)$ and from 0.16 to $14.9 \mathrm{ng} \mathrm{m}^{-3}\left(3.4 \mathrm{ng} \mathrm{m}^{-3}\right)$, respectively (Table 1). Their concentrations were higher than those in high Arctic aerosols (average 69 and $514 \mathrm{pg} \mathrm{m}^{-3}$, respectively) (Fu et al., 2009). In addition, concentrations of pinic acid were 7 times higher than pinonic acid, similar to an earlier report (Fu et al., 2009). The vapour pressure of pinic acid is about 2 orders of magnitude lower than pinonic acid (Bhat and Fraser, 2007). Thus, pinic acid can saturate and readily nucleate, being expected to have a higher fraction in the aerosol phase than pinonic acid.

Two novel monoterpene SOA tracers, 3-hydroxyglutaric acid (3-HGA) and 3-methyl-1,2,3-butanetricarboxylic acid (MBTCA), were also detected in these marine aerosols. Both of them are reported to be higher generation products of $\alpha$ pinene photooxidation (Kourtchev et al., 2009; Szmigielski et al., 2007). The concentration ranges of 3-HGA in marine aerosols over the ECS were lower than those of aerosols in Mt Tai, central east China (Fu et al., 2010), but comparable to other studies about marine aerosols ( $\mathrm{Fu}$ et al., 2011). The average abundance of atmospheric MBTCA for all samples was $5.6 \mathrm{ng} \mathrm{m}^{-3}$, with mean concentrations of 6.8 and $4.5 \mathrm{ng} \mathrm{m}^{-3}$ during the day and night, respectively, more abundant than 3 -HGA $\left(2.2 \mathrm{ng} \mathrm{m}^{-3}\right)$. Interestingly, these mean values of MBTCA were comparable to those of mountain aerosols (Fu et al., 2010), but still higher than the marine aerosols collected in the remote seas (Fu et al., 2011). Since the ECS is adjacent to mainland China, the atmospheric boundary layer in these regions would inevitably be affected by continent-derived air masses, as supported by the spatial pattern of individual SOA tracers (Figs. 4 and S1), in particular of the peaks occurring in the coastal areas. Furthermore, in contrast to isoprene SOA tracers, monoterpene SOA tracers commonly exhibit higher average daytime concentrations (Table 1 and Fig. 5), but a $t$ test showed no significant difference $(p>0.05)$ between daytime and nighttime concentrations for both total and individual monoterpene SOA tracers. The concentration ratio of 3-HGA plus MBTCA to pinic acid ((3HGA+MBTCA)/pinic) showed higher values in the terrestrially influenced aerosols (Fig. 6c). In addition, these mass concentration ratios were mostly higher during the daytime (mean 2.0) than nighttime (1.9), indicating that aged aerosols are more abundant in the daytime.

\subsubsection{Sesquiterpene SOA tracers}

The analysis of sesquiterpenes is a great challenge due to their high reactivity and relatively low vapour pressure. However, the aging of $\beta$-caryophyllene-derived SOA has proved its significant effects on all CCN-relevant properties (Asa-Awuku et al., 2009). $\beta$-Caryophyllene is one of the most abundant species among sesquiterpenes originating from plants (Duhl et al., 2008). $\beta$-Caryophyllinic acid is an ozonolysis or photooxidation product of $\beta$-caryophyllene (Jaoui et al., 2007). Moreover, sesquiterpenes accumulated in leaves and woods can be emitted during biomass combustion (Ciccioli et al., 2014).

The atmospheric levels of $\beta$-caryophyllinic acid were $0.16-17.2 \mathrm{ng} \mathrm{m}^{-3}$ (mean $2.9 \mathrm{ng} \mathrm{m}^{-3}$ ), with $0.17-$ $17.2 \mathrm{ng} \mathrm{m}^{-3}\left(3.5 \mathrm{ng} \mathrm{m}^{-3}\right)$ during the daytime and $0.16-$ $9.6 \mathrm{ng} \mathrm{m}^{-3}\left(2.3 \mathrm{ng} \mathrm{m}^{-3}\right)$ during the nighttime, respectively (Table 1). As expected, $\beta$-caryophyllinic acid correlated well with levoglucosan $(p<0.001, r=0.61, \quad N=51)$ in agreement with an earlier report (Ding et al., 2016), indicating the substantial contribution of terrestrial biomass burning to sesquiterpenes' loading in the marine atmosphere. On the other hand, biomass burning processes (e.g. crop straw combustion and forest fires) can raise ambient and/or leaf temperature to some extent, consequently probably enhancing the emission of sesquiterpenes from trees and plants.

Many studies have proved that sesquiterpene emissions increase significantly with increasing ambient temperatures (Tarvainen et al., 2005; Jaoui et al., 2007). Ambient temperature seems to be the dominant factor controlling temporal variation in sesquiterpene emission, although other factors contribute too (Duhl et al., 2008). An earlier study reported that emission rates of sesquiterpene were 1.2-3 times higher in the daytime as well (Duhl et al., 2008). All the reports described above perfectly interpret much higher concentrations of $\beta$-caryophyllinic acid during the daytime in our study. The abundance of $\beta$-caryophyllinic acid in this study is higher than that reported in the remote marine aerosols during a round-the-world cruise, but is comparable to the maximum concentration of $2.5 \mathrm{ng} \mathrm{m}^{-3}$ observed on the Californian coast (Fu et al., 2011); however, the concentrations of $\beta$-caryophyllinic acid were much lower than those of $\mathrm{Mt}$ Tai aerosols, central east China (average $12 \mathrm{ng} \mathrm{m}^{-3}$ for both daytime and nighttime aerosols) (Fu et al., 2010). The spatial distributions of $\beta$-caryophyllinic acid also presented higher levels in coastal regions than other sampling sites (Fig. 4h), again proving the contribution of terrestrial aerosols. 
Table 2. Concentrations of organic carbon $(\mathrm{OC})\left(\mathrm{ngC} \mathrm{m}^{-3}\right)$ from biogenic primary emission (biomass burning OC and fungal spore OC) and biogenic SOC and their contributions to aerosol OC (\%) in marine aerosols over the East China Sea.

\begin{tabular}{|c|c|c|c|c|c|c|c|c|c|}
\hline \multirow[t]{2}{*}{ Component } & \multicolumn{3}{|c|}{ Total } & \multicolumn{3}{|c|}{ Daytime } & \multicolumn{3}{|c|}{ Nighttime } \\
\hline & Range & Mean & SD & Range & Mean & SD & Range & Mean & SD \\
\hline \multicolumn{10}{|c|}{ Concentration $\left(\mathrm{ngC} \mathrm{m}^{-3}\right)$} \\
\hline Aerosol OC & $424-14100$ & 4260 & 3480 & $1030-14100$ & 4940 & 3800 & $424-9830$ & 3600 & 3080 \\
\hline Biomass burning OC & $1.1-790$ & 89.6 & 156 & $1.1-506$ & 75.5 & 117 & $1.3-790$ & 103 & 187 \\
\hline Fungal spore OC & $1.2-1840$ & 180 & 334 & $1.3-911$ & 157 & 249 & $1.2-1840$ & 203 & 403 \\
\hline Isoprene SOC* & $0.78-324$ & 39.8 & 55.4 & $2.3-133$ & 32.1 & 37.6 & $0.78-324$ & 47.2 & 68.3 \\
\hline Monoterpene SOC & $1.1-377$ & 50.2 & 72.0 & $1.9-377$ & 56.1 & 84.3 & $1.1-189$ & 44.6 & 58.9 \\
\hline Sesquiterpene SOC & $6.9-747$ & 126 & 153 & 7.4-747 & 153 & 183 & $6.9-416$ & 100 & 114 \\
\hline Sum of biogenic SOC & $11.3-1060$ & 216 & 250 & $13.7-1060$ & 241 & 279 & $11.3-824$ & 192 & 222 \\
\hline Subtotal & $16.1-3460$ & 486 & 688 & $29.8-2480$ & 473 & 600 & $16.1-3460$ & 498 & 776 \\
\hline \multicolumn{10}{|c|}{ Percentage in aerosol OC $(\%)$} \\
\hline Biomass burning OC & $0.05-8.5$ & 1.5 & 1.8 & $0.05-4.4$ & 1.1 & 1.2 & $0.13-8.5$ & 1.8 & 2.3 \\
\hline Fungal spore OC & $0.03-19.8$ & 3.1 & 4.0 & $0.03-16.6$ & 2.6 & 3.7 & $0.18-19.7$ & 3.5 & 4.2 \\
\hline Isoprene SOC & $0.13-3.8$ & 0.83 & 0.87 & $0.13-2.0$ & 0.60 & 0.54 & $0.14-3.8$ & 1.0 & 1.1 \\
\hline Monoterpene SOC & $0.08-3.5$ & 0.98 & 0.90 & $0.10-3.3$ & 1.00 & 0.95 & $0.08-3.5$ & 0.96 & 0.87 \\
\hline Sesquiterpene SOC & $0.36-5.3$ & 2.4 & 1.2 & $0.36-5.3$ & 2.5 & 1.4 & $0.87-5.1$ & 2.4 & 1.1 \\
\hline Sum of biogenic SOC & $0.67-9.3$ & 4.2 & 2.2 & $0.67-9.3$ & 4.1 & 2.2 & $1.8-8.8$ & 4.4 & 2.2 \\
\hline Subtotal & $1.5-37.0$ & 8.7 & 6.9 & $1.5-27.4$ & 7.8 & 6.3 & $2.8-37.0$ & 9.7 & 7.4 \\
\hline
\end{tabular}

* The total mass concentrations of SOC produced by isoprene (2-methylglyceric acid and 2-methyltetrols were used), $\alpha / \beta$-pinene, and $\beta$-caryophyllene were estimated using the tracer-based method by Kleindienst et al. (2007).

\subsection{Contributions of biogenic primary and secondary sources}

To assess the relative abundances of organic aerosols from primary and secondary emission sources, tracer-based methods are employed to evaluate their contributions to the marine ambient OC. For example, mannitol and arabitol determined in marine aerosols were used to calculate the contributions of fungal spores to OC (Bauer et al., 2008); the average mass percent ratios of levoglucosan to OC $(8.14 \%)$ are used to investigate the biomass-burning-derived $\mathrm{OC}(\mathrm{Fu}$ et al., 2014). Further, biogenic SOA tracers detected in the present study are utilized to evaluate the SOC formation resulting from the oxidation of isoprene, $\alpha$-pinene, and $\beta$ caryophyllene through a tracer-based method reported by Kleindienst et al. (2007). This method used the laboratoryderived mass fractions $\left(f_{\mathrm{soc}}\right)$ of marker species generated from known precursors into SOC concentrations. Specifically, the $f_{\text {soc }}$ values used in our study are $0.155 \pm 0.039$ for isoprene, $0.231 \pm 0.111$ for $\alpha$-pinene, and $0.023 \pm 0.005$ for $\beta$-caryophyllene, respectively (Kleindienst et al., 2007). Through dividing the sum of tracer compounds measured in these marine samples by $f_{\mathrm{soc}}$, an estimate of the contribution of each SOA to the total marine SOC concentration was determined, and the results are presented in Table 2.
Biomass-burning-derived OC in the whole samples is in the range of $1.1-790 \mathrm{ngC} \mathrm{m}^{-3}\left(89.6 \mathrm{ngC} \mathrm{m}^{-3}\right)$, with higher levels in the nighttime $\left(1.3-790,103 \mathrm{ngC} \mathrm{m}^{-3}\right)$ compared to those $\left(1.1-506,75.5 \mathrm{ngC} \mathrm{m}^{-3}\right)$ in the daytime. Higher concentrations of biomass burning OC near the Asian continent than those over the remote oceans (Fig. 7) suggest that continental biomass burning tracers were possibly removed by dry and/or wet deposition of airborne particles, photodegradation by free radicals in the atmosphere, or other atmospheric dilution mechanisms during long-range transport to the western North Pacific. Fungal-spore-derived OC for all samples ranged from 1.2 to $1840 \mathrm{ngC} \mathrm{m}^{-3}\left(180 \mathrm{ngC} \mathrm{m}^{-3}\right)$, accounting for $0.03-19.8 \%$ (3.1\%) of OC, higher than that of biomass-burning-derived OC (Table 2). The nighttime fungal-spore-derived OC $\left(1.2-1840,203 \mathrm{ngC} \mathrm{m}^{-3}\right)$ is higher than that in the daytime $\left(1.3-911,157 \mathrm{ngC} \mathrm{m}^{-3}\right)$, possibly associated with intensified activities of yeasts and fungi during the nighttime (Fu et al., 2012). As we all know, evenings tend to have a higher moist content, which exerts a stronger influence on microbial activity than temperature (Liang et al., 2003). Similar higher levels of fungalspore-derived OC were also observed in the aerosols collected in coastline waters, probably due to more intensified microbial activities in the coastal regions as discussed previously. $\beta$-Caryophyllene SOC $(6.9-747,126$, with 7.4 $747 \mathrm{ngC} \mathrm{m}^{-3}$, mean $153 \mathrm{ngC} \mathrm{m}^{-3}$ during the day and 6.9- 


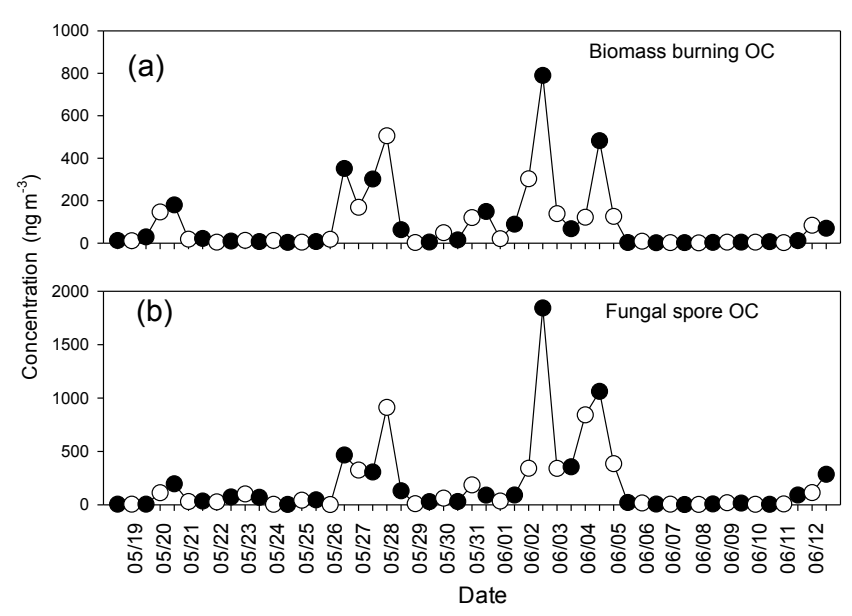

Figure 7. Temporal variations in (a) biomass-burning-derived OC and (b) fungal-spore-derived OC in the marine aerosols over the East China Sea. The open and shaded circles represent daytime and nighttime samples, respectively.

$416 \mathrm{ngC} \mathrm{m}^{-3}$, mean $100 \mathrm{ngC} \mathrm{m}^{-3}$ at night) is found to be a dominant contributor among the measured biogenic SOCs over the ECS (the average concentrations were 39.8 and $50.2 \mathrm{ngC} \mathrm{m}^{-3}$ for isoprene SOC and $\alpha / \beta$-pinene SOC, respectively). Moreover, $\beta$-caryophyllene SOC accounts for $0.36 \%-5.3 \%(2.4 \%)$ of OC, about $2-3$ times as high as that of isoprene $(0.13 \%-3.8 \%, 0.83 \%)$ and monoterpene SOC $(0.08 \%-3.5 \%, 0.98 \%)$. Therefore, an emission inventory for sesquiterpenes in marine aerosols over the ECS will be helpful for the further understanding of the formation of biogenic SOA in this region. Zhu et al. (2016) also reported that the sesquiterpene-derived SOC was more abundant than isoprene- and monoterpene-derived SOC for the aerosols collected in Okinawa, Japan.

The higher levels of sesquiterpene SOC than monoterpene and isoprene SOC may be due to the differences in the gas-particle partitioning of oxidation products from different VOCs, given that longer chain sesquiterpenes $\left(\mathrm{C}_{15} \mathrm{H}_{24}\right)$ have more carbon atoms than monoterpenes $\left(\mathrm{C}_{10} \mathrm{H}_{16}\right)$ and isoprene $\left(\mathrm{C}_{5} \mathrm{H}_{8}\right)$, decreasing the vapour pressures of their oxidation products (Fu et al., 2016). The levels of SOCs stemmed from isoprene, monoterpenes, and sesquiterpene in the marine aerosols over the ECS were much lower than those of $\mathrm{PM}_{2.5}$ samples in Hong Kong, China, during summer (Hu et al., 2008) and those observed in Mt Tai aerosols (Fu et al., 2010). The sum of biogenic SOCs over the ECS is 11.3-1060 $\mathrm{ngC} \mathrm{m}^{-3}\left(216 \mathrm{ngC} \mathrm{m}^{-3}\right)$, much lower than those in the Mt Fuji aerosols $\left(227-1120,542 \mathrm{ngC} \mathrm{m}^{-3}\right.$ ) (Fu et al., 2014) and those in the Mt Tai aerosols (420-3100 $\mathrm{ngC} \mathrm{m}^{-3}$ ) (Fu et al., 2010), but higher than those observed in marine aerosols collected during a round-the-world cruise covering most remote oceans (Fu et al., 2011) and those reported in the Arctic aerosols (average $14.6 \mathrm{ngC} \mathrm{m}^{-3}$ ) (Fu et al., 2009). Such a difference between terrestrial aerosols and ma- rine aerosols highlights the outflow of continental aerosols again. In terms of spatial distributions, biogenic SOCs calculated from these compounds showed higher loadings in the locations close to the coastline or significantly influenced by terrestrial air (Fig. 8a-b), also validating the strong influence of the continental origin. Generally, the total concentrations of biogenic SOC $\left(216 \mathrm{ngC} \mathrm{m}^{-3}\right)$ are higher than those of biomass-burning-derived OC $\left(89.6 \mathrm{ngC} \mathrm{m}^{-3}\right)$ and fungal-spore-derived $\mathrm{OC}\left(180 \mathrm{ngC} \mathrm{m}^{-3}\right)$ (Table 2), presenting a greater contribution from biogenic SOA to the marine aerosols, in agreement with the report by Fu et al. (2014).

In order to compare the relative contribution of marine and continental sources to total OC in the oceanic atmosphere, the whole sampling area was divided into five regions from north to south according to the spatial distribution of aerosol samples, i.e. northern waters of the ECS, nearby waters in the ECS, seas adjacent to Fujian and Zhejiang provinces, and the eastern waters of Taiwan. A 5-day HYSPLIT back trajectory analysis showed that the atmosphere over waters north of the ECS was mainly controlled by marine air masses, while aerosol samples achieved on 12 June showed a great influence from South Korea and North China as well (Fig. S2). Aerosol samples in waters of the ECS were basically under the control of marine air masses, except for the samples collected on 20 May, which were also affected by terrestrial air from the Asian mainland (Fig. S3). In general, aerosols collected off the eastern coast of the island of Taiwan were affected by air masses from the remote sea, but some aerosols collected on 22-23 May were also influenced by air masses coming from Southeast Asia (Fig. S4). In contrast, air masses from the Asian mainland had substantial impacts on the samples collected near Fujian and Zhejiang provinces (Figs. S5S6). On the whole, the aerosols strongly affected by terrestrial sources (e.g. Asian mainland, Southeast Asia, and South Korea) tend to have higher levels of sugars and SOA tracers (Figs. 2 and 4).

The contributions of biomass-burning-derived OC, fungalspore-derived OC, and biogenic SOCs to OC (\%) in these five sampling regions are presented in Fig. 9. Generally, the average contributions of biogenic SOCs, biomass burning OC and fungal spore OC to OC near Zhejiang and Fujian waters were higher than the other sampling areas, especially for the fungal spore OC (7.5 \pm 6.8 for Zhejiang waters, $4.0 \pm 2.8$ for Fujian waters, $2.6 \pm 3.2$ for the northern waters of the ECS, $1.9 \pm 1.7$ for eastern waters of Taiwan, and $1.5 \pm 1.4$ for the ECS, respectively) and biomass burning OC (2.8 \pm 2.6 for Zhejiang waters, $2.7 \pm 1.8$ for Fujian waters, $1.3 \pm 0.92$ for the northern waters of the ECS, $0.52 \pm 0.36$ for eastern waters of Taiwan, and $0.96 \pm 1.7$ for the ECS, respectively). Such spatial variations were closely associated with different contributions of land and marine sources to the oceanic atmosphere.

Figures S2-S6 display a strong influence from land air masses in waters around Zhejiang and Fujian provinces, while the atmosphere over northern waters of the ECS, the 


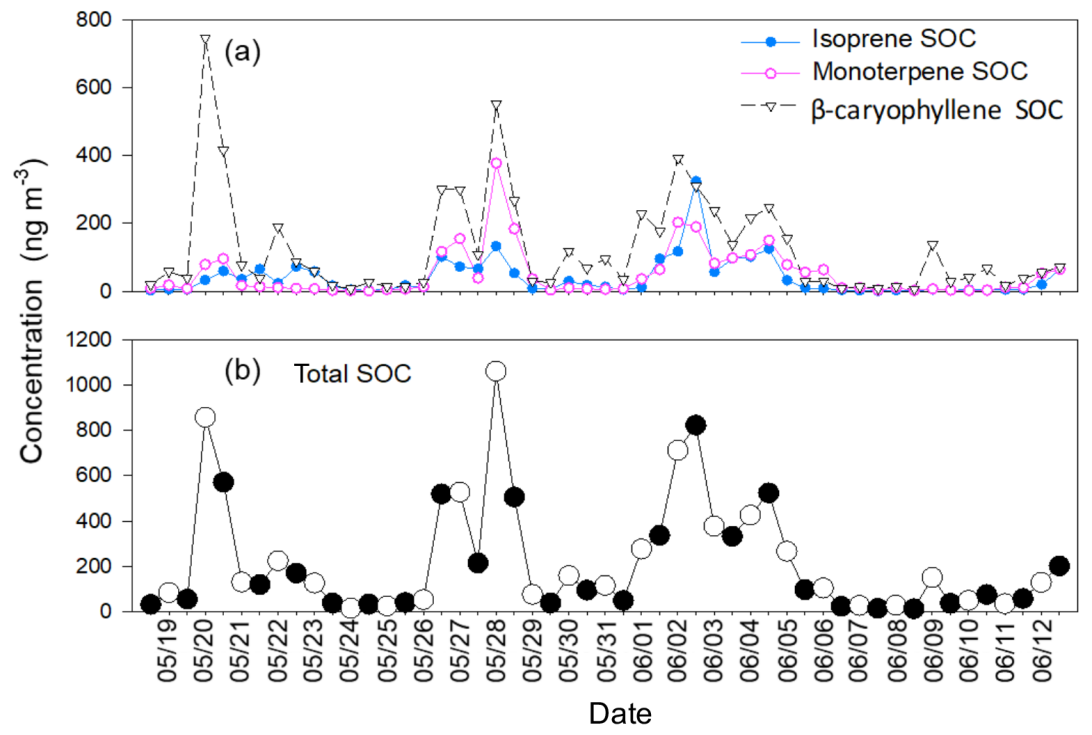

Figure 8. Temporal variations in (a) secondary organic carbon (SOC) derived from isoprene, $\alpha / \beta$-pinene, and sesquiterpene and (b) the total SOC levels in the marine aerosols over the East China Sea during May to June 2014. The open and shaded circles represent the daytime and nighttime samples, respectively.

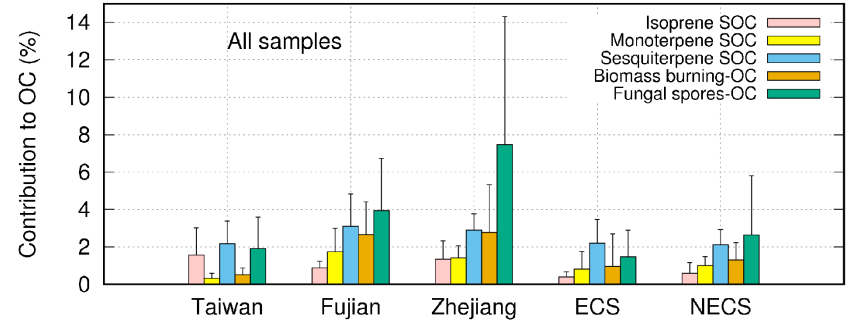

Figure 9. Contributions of $\mathrm{OC}\left(\mathrm{ngC} \mathrm{m}^{-3}\right)$ from biogenic primary emission (biomass burning $\mathrm{OC}$ and fungal spore $\mathrm{OC}$ ) and biogenic SOC to OC $(\%)$ in different sampling regions. Taiwan, Fujian, and Zhejiang refer to the waters around Taiwan, Fujian, and Zhejiang; ECS represents East China Sea waters; NECS represents the northern waters of the ECS.

ECS, and eastern waters of the island of Taiwan basically came under the influence of relatively clean marine air. Interestingly, the average percentage of isoprene SOC in the eastern waters of Taiwan was slightly larger compared to other regions. In light of the back trajectory analysis, aerosols in this region were mainly affected by terrestrial photosynthetic vegetation (e.g. trees and plants) in Southeast Asia and/or marine biota (e.g. phytoplankton, seaweed, and bacteria) (Fig. S4). Sesquiterpene-derived SOC was found to be the most abundant SOC species in all five areas $(2.9 \pm 0.87$ for Zhejiang waters, $3.1 \pm 1.7$ for Fujian waters, $2.1 \pm 0.80$ for the northern waters of the ECS, $2.2 \pm 1.2$ for eastern waters of Taiwan, and $2.2 \pm 1.3$ for the ECS, respectively) in comparison with other SOCs derived from isoprene and monoterpene. On the other hand, the nighttime contributions of biomass burning OC, fungal spore OC, and biogenic SOCs to $\mathrm{OC}$ were commonly greater than the daytime ones in all five regions (Fig. S9). For instance, the contributions of biomass burning $\mathrm{OC}$ and fungal spore $\mathrm{OC}$ to $\mathrm{OC}$ during the nighttime in the seas near Zhejiang $(3.9 \pm 3.5$ and $9.3 \pm 8.0$, respectively) are significantly greater than those in the daytime $(1.9 \pm 1.2$ and $6.0 \pm 6.3$, respectively). Such enhanced contributions in the evening were likely to be in connection with intensified emissions, the decreased height of the PBL, and land-sea breeze circulations at night. The downward movement of the PBL does not facilitate dispersion of pollutants and lead to increases in aerosol concentration in the lower PBL (Li et al., 2017). The prevailing land breeze in the nighttime in coastal areas could bring plentiful terrestrial particles to the clean marine atmosphere. Such a difference between daytime and nighttime contributions illustrates that land-sea breeze circulation and the PBL can be another important factor influencing organics in marine aerosols.

\subsection{Source apportionment by PMF}

\subsubsection{Analysis of source profiles}

After testing runs with a different number of factors (5-9), eight factors were chosen on the basis of the minimum value of $Q$ (goodness of fit parameters) and a probable source profile expected from the study region.

Figure 10 illustrates that the first source had high loadings of $\mathrm{Na}^{+}(90.8 \%)$, suggesting a contribution from sea salt. This profile also contained a significant amount of $\mathrm{SO}_{4}^{2-}$, which can react with sea salt particles and release $\mathrm{HCl}$ gas, 


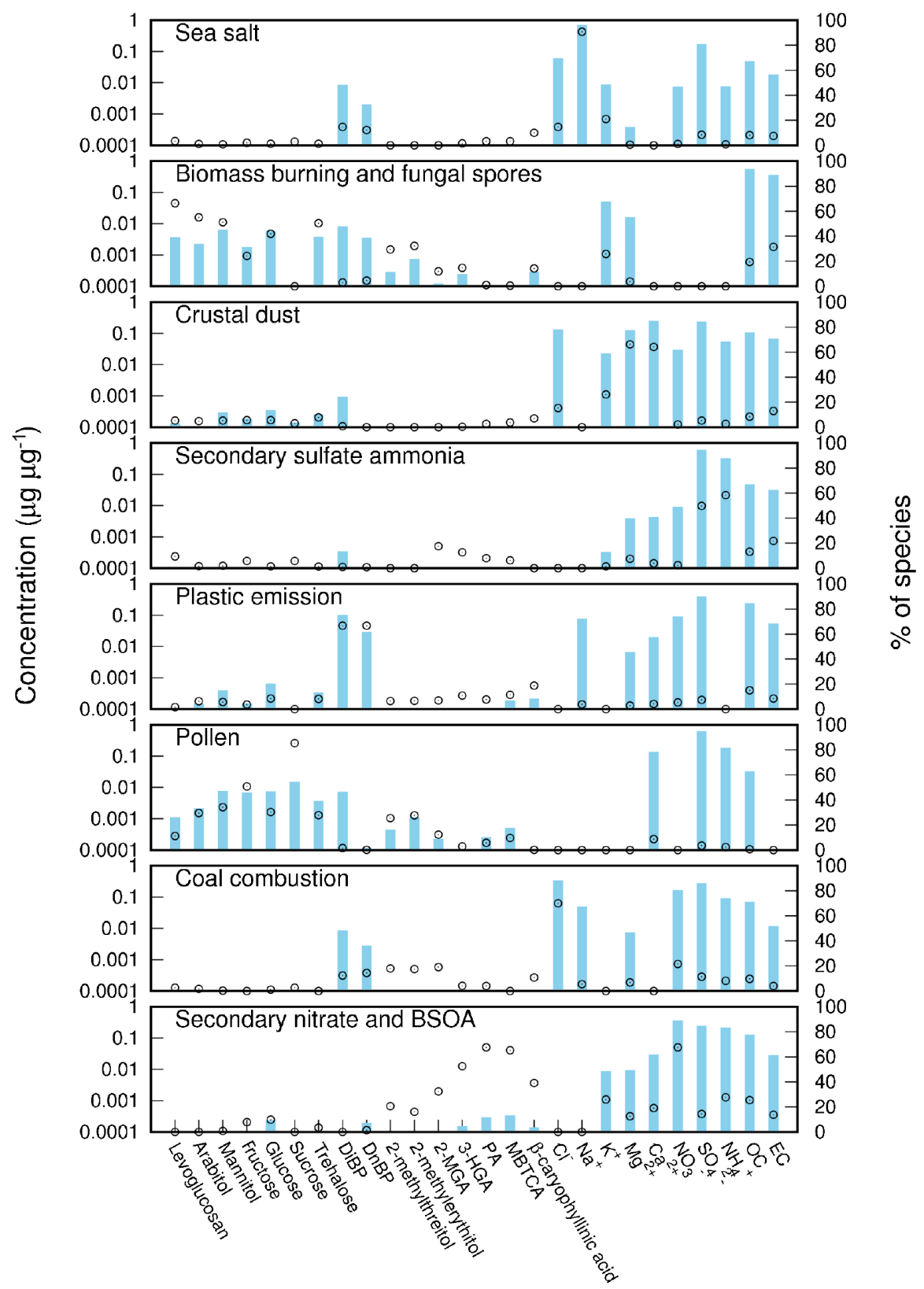

Figure 10. Source profiles identified by PMF. Blue bars represent the mass contribution with the $y$ axis on the left, while black dots stand for the percentage of species to the sum shown by the $y$ axis on the right.

leaving a lower $\mathrm{Cl}^{-} / \mathrm{Na}^{+}$ratio (0.1) than that of seawater (1.8) (Boreddy et al., 2014).

The second source shows high loadings of levoglucosan $(66.3 \%)$, arabitol $(55.0 \%)$, mannitol $(51.1 \%)$, and trehalose $(50.4 \%)$, representing mixed sources of biomass burning and fungal spores (Simoneit et al., 1999; Bauer et al., 2008; Medeiros et al., 2006a). Yang et al. (2012) found an enhanced abundance of fungal tracers on account of biomass burning activities, during which large numbers of fungi could be dispersed into the surrounding atmosphere or be carried upward with the warm plume to other fields via long-distance atmospheric transport.

The third source can be interpreted as crustal dust because of high loadings of $\mathrm{Mg}^{2+}(66.1 \%)$ and $\mathrm{Ca}^{2+}(64.2 \%)$, characteristic elements of soil/crustal dust (Xu et al., 2016). This source may include airborne road dust, construction dust, and windblown soil particles, which are derived primarily from terrestrial sources.

The fourth factor is characterized by the dominance of $\mathrm{NH}_{4}^{+}(58.4 \%)$ and $\mathrm{SO}_{4}^{2-}(49.7 \%)$, which can be classified as secondary ammonium sulfate. The molar ratio of $\mathrm{NH}_{4}^{+}$ 


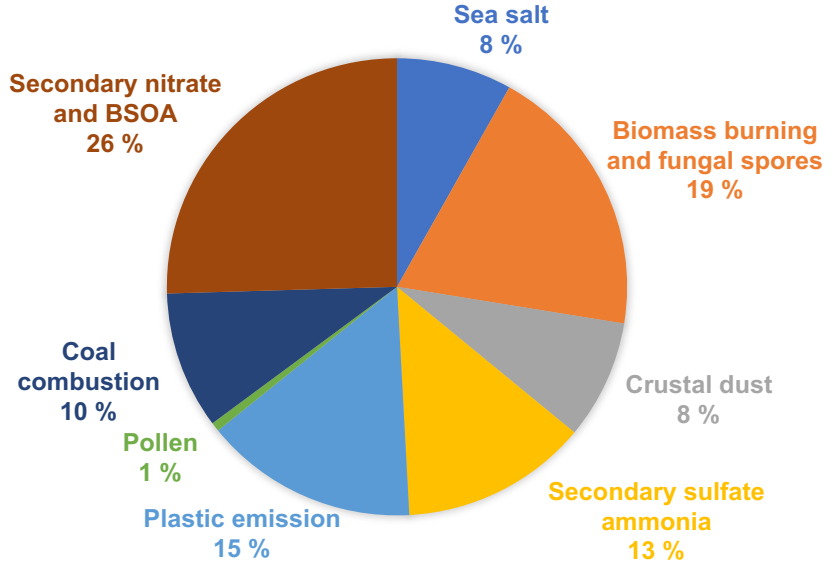

Figure 11. Contributions of different sources to organic carbon (OC) in marine aerosols over the East China Sea.

and $\mathrm{SO}_{4}^{2-}$ was 2.9 in this profile, suggesting that $\left(\mathrm{NH}_{4}\right)_{2} \mathrm{SO}_{4}$ was the dominant sulfate form in the marine atmosphere over the ECS. Due to its long lifetime in the atmosphere, terrestrial $\mathrm{SO}_{4}^{2-}$ could be transported over long distances to coastal areas and even to the remote sea (Itahashi et al., 2017), affecting the chemical composition of oceanic atmosphere.

The fifth factor exhibits high loadings of di-isobutyl (DiBP) and di-n-butyl (DnBP), dominant species of phthalates in the marine aerosols over the ECS, which is assigned to plastic materials' emission likely from industry, agriculture, and domestic application in coastal regions.

The sixth factor has high loadings of sucrose $(85.3 \%)$ followed by fructose $(50.9 \%)$, implying a significant emission from airborne pollen grains to the marine atmosphere over the ECS during late spring to early summer (Fu et al., 2012).

The seventh profile presents high loadings of $\mathrm{Cl}$, likely to be associated with coal combustion, which provides a significant releases of chlorine (McCulloch et al., 1999; Sun et al., 2013). Another confirmation is the high concentration of $\mathrm{SO}_{4}^{2-}$ from this profile, since coal consumption can produce mass sulfate as well.

The eighth factor illustrates high loadings of $\mathrm{NO}_{3}^{-}$ $(67.5 \%)$ and biogenic SOA tracers, especially the monoterpene SOA tracers, i.e. PA (67.5\%) and MBTCA $(65.2 \%)$. This factor could be attributed to the photochemical oxidation products stemmed from the emission of vehicle and biogenic VOCs. Formation of secondary nitrate depends on $\mathrm{NO}_{x}$, which is mainly produced from power plants and mobile sources (Heo et al., 2009; Kim et al., 2006). Anthropogenic $\mathrm{NO}_{x}$ could also enhance biogenic SOA formation via nitrate radical oxidation of monoterpenes (Xu et al., 2015). The positive correlations between $\mathrm{NO}_{3}^{-}$and isoprenederived SOA tracers as discussed before in our study also suggest $\mathrm{NO}_{3}^{-}$and BSOA may share common formation and/or transport pathways. Previous studies have reported that nitrogen-containing species play a pivotal part in the for- mation and fate of SOA through varying radical and oxidant regimes and particle properties, such as volatility and hygroscopicity (Chen et al., 2017), agreeing well with our results.

Overall, the eight sources based on PMF were sea salt, biomass burning and fungal spores, crustal dust, secondary sulfate ammonia, plastic emission, pollen grains, coal combustion, and secondary nitrate and BSOA, which contributed to the TSP over the ECS by $16.9 \%, 3.5 \%, 8.0 \%, 28.5 \%$, $6.3 \%, 2.0 \%, 14.3 \%$, and $20.4 \%$, respectively. The results of PMF show that secondary origin and marine natural emissions could be the main sources for the aerosols over the ECS. Figure 11 shows the contributions of different sources to OC in marine aerosols. On the whole, secondary nitrate and BSOA $(25.5 \%)$ and biomass burning and fungal spores (19.5\%) contributed more to OC than other sources during the whole sampling periods, elucidating the significant influence of biogenic primary and secondary sources on marine organic aerosols.

\subsubsection{Temporal and spatial variation in sources}

Figure 12 shows the temporal and spatial variation in each profile during the day and the night. The contribution of each source changes over time and varies with distance from the continent. In general, higher levels contributed by biomass burning, fungal spores, crustal dust, pollen grains, coal combustion, secondary nitrate, and BSOA were basically observed in coastal aerosols and/or terrestrially influenced aerosols, suggesting the strong influence of continental air from East Asia and Southeast Asia in light of the back trajectories and wind directions during the sampling periods (Figs. S2-S6 and S10). However, the contributions from sea salt particles, indicative of oceanic emission (organic components can be emitted from the ocean surface together with sea salt particles via sea spray or bubble bursting), tend to be higher in the aerosols mainly affected by marine air masses. Our study demonstrates that primary and secondary OM of terrestrial origin plays an important role in the marine aerosol chemistry over the western North Pacific through long-range atmospheric transport in addition to natural emission of the ocean.

\section{Conclusions}

In summary, atmospheric concentration, spatial distribution, and source apportionment of sugars and biogenic SOA tracers were studied for the coastal and remote marine aerosols. Higher concentrations of sugars and BSOA tracers were observed in the atmosphere around coastal waters and/or in the terrestrially influenced regions in comparison with the remote oceans, suggesting that continent origin contributed a lot to the abundance of sugars and BSOA tracers in the marine atmosphere. Glucose was the dominant sugar species, followed by mannitol among the total identified sugar com- 


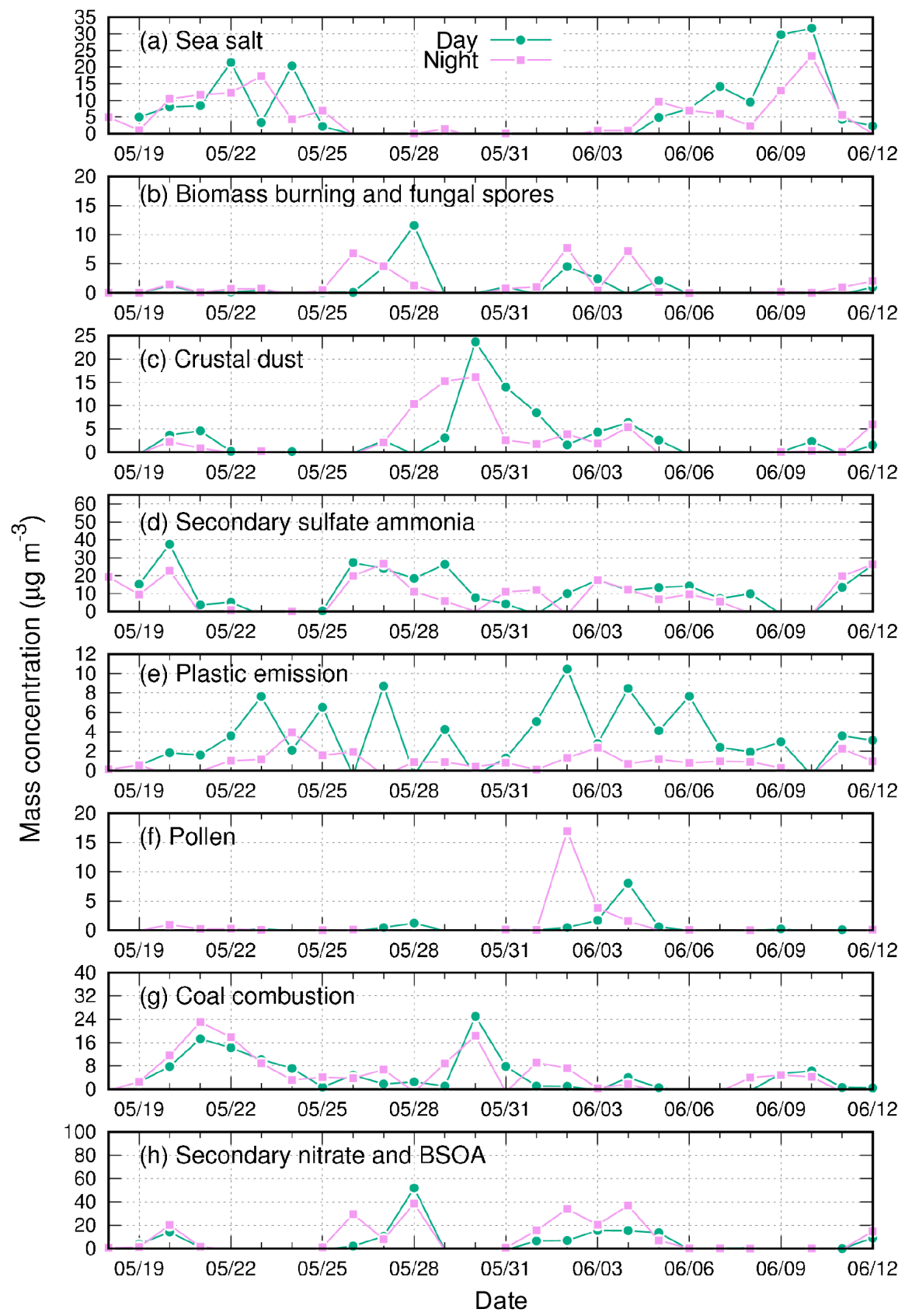

Figure 12. Temporal variation in sources which contributed to marine aerosols $\left(\mu \mathrm{g} \mathrm{m}^{-3}\right)$.

pounds. Biogenic SOC was characterized by a predominance of $\beta$-caryophyllene oxidation products in comparison with isoprene and $\alpha / \beta$-pinene tracers. The contributions of biomass-burning-derived $\mathrm{OC}$, fungal-spore-derived $\mathrm{OC}$, and biogenic SOC to OC (\%) were greater in the marine aerosols affected by land air masses. The results of PMF illustrate that secondary nitrate, BSOA, biomass burning, and fungal spores could be the major contributors to OC in marine aerosols over the ECS. Our study demonstrates that both primary and secondary organic aerosols of terrestrial origin have great influences on the marine aerosol chemistry over the western North Pacific through long-range atmospheric transport.

Data availability. The data for this paper are available upon request from the corresponding author (fupingqing@tju.edu.cn). 
Supplement. The supplement related to this article is available online at: https://doi.org/10.5194/acp-18-13947-2018-supplement.

Author contributions. PF designed and supervised the whole project. FY collected the aerosol samples. MK and FY conducted the experiments. MK and $\mathrm{HZ}$ performed the data analyses. MK wrote the manuscript. All authors contributed to the paper with useful scientific discussions or comments.

Competing interests. The authors declare that they have no conflict of interest.

Acknowledgements. This study was supported by the National Natural Science Foundation of China (grant nos. 41625014, 41475117, 41571130024 and 91543205). We are grateful to the crew of the marine cruise supported by the National Natural Science Foundation of China.

Edited by: Kostas Tsigaridis

Reviewed by: two anonymous referees

\section{References}

Asa-Awuku, A., Engelhart, G. J., Lee, B. H., Pandis, S. N., and Nenes, A.: Relating CCN activity, volatility, and droplet growth kinetics of $\beta$-caryophyllene secondary organic aerosol, Atmos. Chem. Phys., 9, 795-812, https://doi.org/10.5194/acp-9795-2009, 2009.

Atkinson, R. and Arey, J.: Atmospheric Degradation of Volatile Organic Compounds, Chem. Rev., 103, 4605-4638, https://doi.org/10.1021/cr0206420, 2003.

Baker, H. G., Baker, I., and Hodges, S. A.: Sugar Composition of Nectars and Fruits Consumed by Birds and Bats in the Tropics and Subtropics1, Biotropica, 30, 559-586, https://doi.org/10.1111/j.1744-7429.1998.tb00097.x, 1998.

Bauer, H., Claeys, M., Vermeylen, R., Schueller, E., Weinke, G., Berger, A., and Puxbaum, H.: Arabitol and mannitol as tracers for the quantification of airborne fungal spores, Atmos. Environ., 42, 588-593, https://doi.org/10.1016/j.atmosenv.2007.10.013, 2008.

Bhat, S. and Fraser, M. P.: Primary source attribution and analysis of $\alpha$-pinene photooxidation products in Duke Forest, North Carolina, Atmos. Environ., 41, 2958-2966, https://doi.org/10.1016/j.atmosenv.2006.12.018, 2007.

Bikkina, S., Kawamura, K., Miyazaki, Y., and Fu, P.: High abundances of oxalic, azelaic, and glyoxylic acids and methylglyoxal in the open ocean with high biological activity: Implication for secondary OA formation from isoprene, Geophys. Res. Lett., 41, 3649-3657, https://doi.org/10.1002/2014GL059913, 2014.

Boreddy, S. K. R., Kawamura, K., and Jung, J.: Hygroscopic properties of particles nebulized from water extracts of aerosols collected at Chichijima Island in the western North Pacific: An outflow region of Asian dust, J. Geophys. Res.-Atmos., 119, 167178, https://doi.org/10.1002/2013JD020626, 2014.

Bougiatioti, A., Nenes, A., Fountoukis, C., Kalivitis, N., Pandis, S. N., and Mihalopoulos, N.: Size-resolved CCN distributions and activation kinetics of aged continental and marine aerosol, Atmos. Chem. Phys., 11, 8791-8808, https://doi.org/10.5194/acp11-8791-2011, 2011.

Burshtein, N., Lang-Yona, N., and Rudich, Y.: Ergosterol, arabitol and mannitol as tracers for biogenic aerosols in the eastern Mediterranean, Atmos. Chem. Phys., 11, 829-839, https://doi.org/10.5194/acp-11-829-2011, 2011.

Cahill, T. M., Seaman, V. Y., Charles, M. J., Holzinger, R., and Goldstein, A. H.: Secondary organic aerosols formed from oxidation of biogenic volatile organic compounds in the Sierra Nevada Mountains of California, J. Geophys. Res.-Atmos., 111, D16312, https://doi.org/10.1029/2006JD007178, 2006.

Cao, F., Zhang, Y., Ren, L., Liu, J., Li, J., Zhang, G., Liu, D., Sun, Y., Wang, Z., Shi, Z., and Fu, P.: New insights into the sources and formation of carbonaceous aerosols in China: potential applications of dual-carbon isotopes, Nat. Sci. Rev., 4, 804-806, https://doi.org/10.1093/nsr/nwx097, 2017.

Cavalli, F., Facchini, M. C., Decesari, S., Mircea, M., Emblico, L., Fuzzi, S., Ceburnis, D., Yoon, Y. J., O’Dowd, C. D., Putaud, J. P., and Dell'Acqua, A.: Advances in characterization of size-resolved organic matter in marine aerosol over the North Atlantic, J. Geophys. Res.-Atmos., 109, D24215, https://doi.org/10.1029/2004JD005137, 2004.

Chen, J., Kawamura, K., Liu, C.-Q., and Fu, P.: Long-term observations of saccharides in remote marine aerosols from the western North Pacific: A comparison between 19901993 and 2006-2009 periods, Atmos. Environ., 67, 448-458, https://doi.org/10.1016/j.atmosenv.2012.11.014, 2013.

Chen, Q., Fu, T.-M., Hu, J., Ying, Q., and Zhang, L.: Modeling Secondary Organic Aerosol in China, Nat. Sci. Rev., 4, 806-809, https://doi.org/10.1093/nsr/nwx143, 2017.

Ciccioli, P., Centritto, M., and Loreto, F.: Biogenic volatile organic compound emissions from vegetation fires, Plant Cell Environ., 37, 1810-1825, https://doi.org/10.1111/pce.12336, 2014.

Claeys, M., Graham, B., Vas, G., Wang, W., Vermeylen, R., Pashynska, V., Cafmeyer, J., Guyon, P., Andreae, M. O., Artaxo, P., and Maenhaut, W.: Formation of Secondary Organic Aerosols Through Photooxidation of Isoprene, Science, 303, 1173-1176, https://doi.org/10.1126/science.1092805, 2004a.

Claeys, M., Wang, W., Ion, A. C., Kourtchev, I., Gelencsér, A., and Maenhaut, W.: Formation of secondary organic aerosols from isoprene and its gas-phase oxidation products through reaction with hydrogen peroxide, Atmos. Environ., 38, 4093-4098, https://doi.org/10.1016/j.atmosenv.2004.06.001, 2004b.

Claeys, M., Szmigielski, R., Kourtchev, I., Van der Veken, P., Vermeylen, R., Maenhaut, W., Jaoui, M., Kleindienst, T. E., Lewandowski, M., Offenberg, J. H., and Edney, E. O.: Hydroxydicarboxylic Acids:? Markers for Secondary Organic Aerosol from the Photooxidation of $\alpha$-Pinene, Environ. Sci. Technol., 41, 1628-1634, https://doi.org/10.1021/es0620181, 2007.

Cong, Z. Y., Kawamura, K., Kang, S. C., and Fu, P. Q.: Penetration of biomass-burning emissions from South Asia through the Himalayas: new insights from atmospheric organic acids, Sci. Rep., 5, 9580, https://doi.org/10.1038/srep09580, 2015.

Ding, X., He, Q.-F., Shen, R.-Q., Yu, Q.-Q., and Wang, X.M.: Spatial distributions of secondary organic aerosols from isoprene, monoterpenes, $\beta$-caryophyllene, and aromatics over China during summer, J. Geophys. Res.-Atmos., 119, 1187711891, https://doi.org/10.1002/2014JD021748, 2014. 
Ding, X., Zhang, Y.-Q., He, Q.-F., Yu, Q.-Q., Shen, R.-Q., Zhang, Y., Zhang, Z., Lyu, S.-J., Hu, Q.-H., Wang, Y.-S., Li, L.-F., Song, W., and Wang, X.-M.: Spatial and seasonal variations of secondary organic aerosol from terpenoids over China, J. Geophys. Res.-Atmos., 121, 14661-14678, https://doi.org/10.1002/2016JD025467, 2016.

Duhl, T. R., Helmig, D., and Guenther, A.: Sesquiterpene emissions from vegetation: a review, Biogeosciences, 5, 761-777, https://doi.org/10.5194/bg-5-761-2008, 2008.

Edney, E. O., Kleindienst, T. E., Jaoui, M., Lewandowski, M., Offenberg, J. H., Wang, W., and Claeys, M.: Formation of 2methyl tetrols and 2-methylglyceric acid in secondary organic aerosol from laboratory irradiated isoprene/NOX/SO2/air mixtures and their detection in ambient PM2.5 samples collected in the eastern United States, Atmos. Environ., 39, 5281-5289, https://doi.org/10.1016/j.atmosenv.2005.05.031, 2005.

Fabbri, D., Torri, C., Simoneit, B. R. T., Marynowski, L., Rushdi, A. I., and Fabiańska, M. J.: Levoglucosan and other cellulose and lignin markers in emissions from burning of Miocene lignites, Atmos. Environ., 43, 2286-2295, https://doi.org/10.1016/j.atmosenv.2009.01.030, 2009.

Facchini, M. C., Decesari, S., Rinaldi, M., Carbone, C., Finessi, E., Mircea, M., Fuzzi, S., Moretti, F., Tagliavini, E., Ceburnis, D., and O'Dowd, C. D.: Important Source of Marine Secondary Organic Aerosol from Biogenic Amines, Environ. Sci. Technol., 42, 9116-9121, https://doi.org/10.1021/es8018385, 2008.

Feng, X. and Simpson, M. J.: The distribution and degradation of biomarkers in Alberta grassland soil profiles, Org. Geochem., 38, 1558-1570, https://doi.org/10.1016/j.orggeochem.2007.05.001, 2007.

Fu, P., Kawamura, K., Okuzawa, K., Aggarwal, S. G., Wang, G., Kanaya, Y., and Wang, Z.: Organic molecular compositions and temporal variations of summertime mountain aerosols over Mt. Tai, North China Plain, J. Geophys. Res.-Atmos., 113, D19107, https://doi.org/10.1029/2008JD009900, 2008.

Fu, P., Kawamura, K., Chen, J., and Barrie, L. A.: Isoprene, Monoterpene, and Sesquiterpene Oxidation Products in the High Arctic Aerosols during Late Winter to Early Summer, Environ. Sci. Technol., 43, 4022-4028, https://doi.org/10.1021/es803669a, 2009.

Fu, P., Kawamura, K., Kanaya, Y., and Wang, Z.: Contributions of biogenic volatile organic compounds to the formation of secondary organic aerosols over Mt. Tai, Central East China, Atmos. Environ., 44, 4817-4826, https://doi.org/10.1016/j.atmosenv.2010.08.040, 2010.

$\mathrm{Fu}$, P., Kawamura, K., and Miura, K.: Molecular characterization of marine organic aerosols collected during a roundthe-world cruise, J. Geophys. Res.-Atmos., 116, D13302, https://doi.org/10.1029/2011JD015604, 2011.

Fu, P., Kawamura, K., Kobayashi, M., and Simoneit, B. R. T.: Seasonal variations of sugars in atmospheric particulate matter from Gosan, Jeju Island: Significant contributions of airborne pollen and Asian dust in spring, Atmos. Environ., 55, 234-239, https://doi.org/10.1016/j.atmosenv.2012.02.061, 2012.

Fu, P., Kawamura, K., Chen, J., and Miyazaki, Y.: Secondary Production of Organic Aerosols from Biogenic VOCs over Mt. Fuji, Japan, Environ. Sci. Technol., 48, 8491-8497, https://doi.org/10.1021/es500794d, 2014.
Fu, P., Aggarwal, S. G., Chen, J., Li, J., Sun, Y., Wang, Z., Chen, H., Liao, H., Ding, A., Umarji, G. S., Patil, R. S., Chen, Q., and Kawamura, K.: Molecular Markers of Secondary Organic Aerosol in Mumbai, India, Environ. Sci. Technol., 50, 46594667, https://doi.org/10.1021/acs.est.6b00372, 2016.

Gantt, B. and Meskhidze, N.: The physical and chemical characteristics of marine primary organic aerosol: a review, Atmos. Chem. Phys., 13, 3979-3996, https://doi.org/10.5194/acp13-3979-2013, 2013.

Gantt, B., Meskhidze, N., and Kamykowski, D.: A new physicallybased quantification of marine isoprene and primary organic aerosol emissions, Atmos. Chem. Phys., 9, 4915-4927, https://doi.org/10.5194/acp-9-4915-2009, 2009.

Gershey, R. M.: Characterization of seawater organic matter carried by bubble-generated aerosols1, Limnol. Oceanogr., 28, 309-319, https://doi.org/10.4319/lo.1983.28.2.0309, 1983.

Glasius, M., Lahaniati, M., Calogirou, A., Di Bella, D., Jensen, N. R., Hjorth, J., Kotzias, D., and Larsen, B. R.: Carboxylic Acids in Secondary Aerosols from Oxidation of Cyclic Monoterpenes by Ozone, Environ. Sci. Technol., 34, 1001-1010, https://doi.org/10.1021/es990445r, 2000.

Goldstein, A. H. and Galbally, I. E.: Known and Unexplored Organic Constituents in the Earth's Atmosphere, Environ. Sci Technol., 41, 1514-1521, https://doi.org/10.1021/es072476p, 2007.

Graham, B., Guyon, P., Taylor, P. E., Artaxo, P., Maenhaut, W., Glovsky, M. M., Flagan, R. C., and Andreae, M. O.: Organic compounds present in the natural Amazonian aerosol: Characterization by gas chromatography-mass spectrometry, J. Geophys. Res.-Atmos., 108, D24, https://doi.org/10.1029/2003JD003990, 2003.

Griffin, R. J., Cocker, D. R., Seinfeld, J. H., and Dabdub, D.: Estimate of global atmospheric organic aerosol from oxidation of biogenic hydrocarbons, Geophys. Res. Lett., 26, 2721-2724, https://doi.org/10.1029/1999GL900476, 1999.

Guenther, A., Karl, T., Harley, P., Wiedinmyer, C., Palmer, P. I., and Geron, C.: Estimates of global terrestrial isoprene emissions using MEGAN (Model of Emissions of Gases and Aerosols from Nature), Atmos. Chem. Phys., 6, 3181-3210, https://doi.org/10.5194/acp-6-3181-2006, 2006.

Hackenberg, S. C., Andrews, S. J., Airs, R., Arnold, S. R., Bouman, H. A., Brewin, R. J. W., Chance, R. J., Cummings, D., Dall'Olmo, G., Lewis, A. C., Minaeian, J. K., Reifel, K. M., Small, A., Tarran, G. A., Tilstone, G. H., and Carpenter, L. J.: Potential controls of isoprene in the surface ocean, Global Biogeochem. Cy., 31, 644-662, https://doi.org/10.1002/2016GB005531, 2017.

Hallquist, M., Wenger, J. C., Baltensperger, U., Rudich, Y., Simpson, D., Claeys, M., Dommen, J., Donahue, N. M., George, C., Goldstein, A. H., Hamilton, J. F., Herrmann, H., Hoffmann, T., Iinuma, Y., Jang, M., Jenkin, M. E., Jimenez, J. L., Kiendler-Scharr, A., Maenhaut, W., McFiggans, G., Mentel, Th. F., Monod, A., Prévôt, A. S. H., Seinfeld, J. H., Surratt, J. D., Szmigielski, R., and Wildt, J.: The formation, properties and impact of secondary organic aerosol: current and emerging issues, Atmos. Chem. Phys., 9, 5155-5236, https://doi.org/10.5194/acp9-5155-2009, 2009.

Han, F., Kota, S. H., Wang, Y., and Zhang, H.: Source apportionment of PM2.5 in Baton Rouge, Louisiana 
during 2009-2014, Sci. Total Environ., 586, 115-126, https://doi.org/10.1016/j.scitotenv.2017.01.189, 2017.

Hawkins, L. N., Russell, L. M., Covert, D. S., Quinn, P. K., and Bates, T. S.: Carboxylic acids, sulfates, and organosulfates in processed continental organic aerosol over the southeast Pacific Ocean during VOCALS-REx 2008, J. Geophys. Res.-Atmos., 115, D13201, https://doi.org/10.1029/2009JD013276, 2010.

Heo, J.-B., Hopke, P. K., and Yi, S.-M.: Source apportionment of $\mathrm{PM}_{2.5}$ in Seoul, Korea, Atmos. Chem. Phys., 9, 4957-4971, https://doi.org/10.5194/acp-9-4957-2009, 2009.

Hoffmann, T., Odum, J. R., Bowman, F., Collins, D., Klockow, D., Flagan, R. C., and Seinfeld, J. H.: Formation of organic aerosols from the oxidation of biogenic hydrocarbons, J. Atmos. Chem., 26, 189-222, 1997.

Hu, D., Bian, Q., Li, T. W. Y., Lau, A. K. H., and Yu, J. Z.: Contributions of isoprene, monoterpenes, $\beta$-caryophyllene, and toluene to secondary organic aerosols in Hong Kong during the summer of 2006, J. Geophys. Res.-Atmos., 113, D22206, https://doi.org/10.1029/2008JD010437, 2008.

Hu, Q.-H., Xie, Z.-Q., Wang, X.-M., Kang, H., He, Q.-F., and Zhang, P.: Secondary organic aerosols over oceans via oxidation of isoprene and monoterpenes from Arctic to Antarctic, Scientific Reports, 3, 2280, https://doi.org/10.1038/srep02280, 2013.

Iinuma, Y., Böge, O., Gnauk, T., and Herrmann, H.: Aerosolchamber study of the $\alpha$-pinene/O3 reaction: influence of particle acidity on aerosol yields and products, Atmos. Environ., 38, 761-773, https://doi.org/10.1016/j.atmosenv.2003.10.015, 2004.

Iinuma, Y., Bruggemann, E., Gnauk, T., Muller, K., Andreae, M. O., Helas, G., Parmar, R., and Herrmann, H.: Source characterization of biomass burning particles: The combustion of selected European conifer, African hardwood, savanna grass, and German and Indonesian peat, J. Geophys. Res.-Atmos, 112, D08209, https://doi.org/10.1029/2006JD007120, 2007.

Ion, A. C., Vermeylen, R., Kourtchev, I., Cafmeyer, J., Chi, X., Gelencsér, A., Maenhaut, W., and Claeys, M.: Polar organic compounds in rural $\mathrm{PM}_{2.5}$ aerosols from K-puszta, Hungary, during a 2003 summer field campaign: Sources and diel variations, Atmos. Chem. Phys., 5, 1805-1814, https://doi.org/10.5194/acp-51805-2005, 2005.

Itahashi, S., Hayami, H., Yumimoto, K., and Uno, I.: Chinese province-scale source apportionments for sulfate aerosol in 2005 evaluated by the tagged tracer method, Environ. Pollut., 220, 1366-1375, https://doi.org/10.1016/j.envpol.2016.10.098, 2017.

Jaoui, M., Kleindienst, T. E., Lewandowski, M., Offenberg, J. H., and Edney, E. O.: Identification and Quantification of Aerosol Polar Oxygenated Compounds Bearing Carboxylic or Hydroxyl Groups. 2. Organic Tracer Compounds from Monoterpenes, Environ. Sci. Technol., 39, 5661-5673, https://doi.org/10.1021/es048111b, 2005.

Jaoui, M., Lewandowski, M., Kleindienst, T. E., Offenberg, J. H., and Edney, E. O.: $\beta$-caryophyllinic acid: An atmospheric tracer for $\beta$-caryophyllene secondary organic aerosol, Geophys. Res. Lett., 34, L05816, https://doi.org/10.1029/2006GL028827, 2007.

Jia, Y. and Fraser, M.: Characterization of Saccharides in Sizefractionated Ambient Particulate Matter and Aerosol Sources: The Contribution of Primary Biological Aerosol Particles (PBAPs) and Soil to Ambient Particulate Matter, Environ. Sci. Technol., 45, 930-936, https://doi.org/10.1021/es103104e, 2011.
Kang, M., Yang, F., Ren, H., Zhao, W., Zhao, Y., Li, L., Yan, Y., Zhang, Y., Lai, S., Zhang, Y., Yang, Y., Wang, Z., Sun, Y., and $\mathrm{Fu}, \mathrm{P}$.: Influence of continental organic aerosols to the marine atmosphere over the East China Sea: Insights from lipids, PAHs and phthalates, Sci. Total Environ., 607-608, 339-350, https://doi.org/10.1016/j.scitotenv.2017.06.214, 2017.

Kim, J. Y., Song, C. H., Ghim, Y. S., Won, J. G., Yoon, S. C., Carmichael, G. R., and Woo, J. H.: An investigation on NH3 emissions and particulate NH4+-NO3- formation in East Asia, Atmos. Environ., 40, 2139-2150, https://doi.org/10.1016/j.atmosenv.2005.11.048, 2006.

Kleindienst, T. E., Jaoui, M., Lewandowski, M., Offenberg, J. H., Lewis, C. W., Bhave, P. V., and Edney, E. O.: Estimates of the contributions of biogenic and anthropogenic hydrocarbons to secondary organic aerosol at a southeastern US location, Atmos. Environ., 41, 8288-8300, https://doi.org/10.1016/j.atmosenv.2007.06.045, 2007.

Kourtchev, I., Copolovici, L., Claeys, M., and Maenhaut, W.: Characterization of Atmospheric Aerosols at a Forested Site in Central Europe, Environ. Sci. Technol., 43, 4665-4671, https://doi.org/10.1021/es803055w, 2009.

Kumar, A., Sudheer, A. K., Goswami, V., and Bhushan, R.: Influence of continental outflow on aerosol chemical characteristics over the Arabian Sea during winter, Atmos. Environ., 50, 182191, https://doi.org/10.1016/j.atmosenv.2011.12.040, 2012.

Kurihara, M. K., Kimura, M., Iwamoto, Y., Narita, Y., Ooki, A., Eum, Y. J., Tsuda, A., Suzuki, K., Tani, Y., Yokouchi, Y., Uematsu, M., and Hashimoto, S.: Distributions of short-lived iodocarbons and biogenic trace gases in the open ocean and atmosphere in the western North Pacific, Mar. Chem., 118, 156170, https://doi.org/10.1016/j.marchem.2009.12.001, 2010.

Li, J., Wang, G., Wu, C., Cao, C., Ren, Y., Wang, J., Li, J., Cao, J., Zeng, L., and Zhu, T.: Characterization of isoprene-derived secondary organic aerosols at a rural site in North China Plain with implications for anthropogenic pollution effects, Sci. Rep., 8, 535, https://doi.org/10.1038/s41598-017-18983-7, 2018.

Li, Z., Guo, J., Ding, A., Liao, H., Liu, J., Sun, Y., Wang, T., Xue, H., Zhang, H., and Zhu, B.: Aerosol and boundary-layer interactions and impact on air quality, Nat. Sci. Rev., 4, 810-833, https://doi.org/10.1093/nsr/nwx117, 2017.

Liang, C., Das, K. C., and McClendon, R. W.: The influence of temperature and moisture contents regimes on the aerobic microbial activity of a biosolids composting blend, Bioresource Technol., 86, 131-137, https://doi.org/10.1016/S0960-8524(02)00153-0, 2003.

Lin, Y. H., Zhang, H., Pye, H. O. T., Zhang, Z., Marth, W. J., Park, S., Arashiro, M., Cui, T., Budisulistiorini, S. H., Sexton, K. G., Vizuete, W., Xie, Y., Luecken, D. J., Piletic, I. R., Edney, E. O., Bartolotti, L. J., Gold, A., and Surratt, J. D.: Epoxide as a precursor to secondary organic aerosol formation from isoprene photooxidation in the present of nitrogen oxides, P. Natl. Acad. Sci. USA, 110, 6718-6723, 2013.

McCulloch, A., Aucott, M. L., Benkovitz, C. M., Graedel, T. E., Kleiman, G., Midgley, P. M., and Li, Y.-F.: Global emissions of hydrogen chloride and chloromethane from coal combustion, incineration and industrial activities: Reactive Chlorine Emissions Inventory, J. Geophys. Res.-Atmos., 104, 8391-8403, https://doi.org/10.1029/1999JD900025, 1999. 
Medeiros, P. M. and Simoneit, B. R. T.: Analysis of sugars in environmental samples by gas chromatographymass spectrometry, J. Chromatogr. A, 1141, 271-278, https://doi.org/10.1016/j.chroma.2006.12.017, 2007.

Medeiros, P. M., Conte, M. H., Weber, J. C., and Simoneit, B. R. T.: Sugars as source indicators of biogenic organic carbon in aerosols collected above the Howland Experimental Forest, Maine, Atmos. Environ., 40, 1694-1705, https://doi.org/10.1016/j.atmosenv.2005.11.001, 2006a.

Medeiros, P. M., Fernandes, M. F., Dick, R. P., and Simoneit, B. R. T.: Seasonal variations in sugar contents and microbial community in a ryegrass soil, Chemosphere, 65, 832-839, https://doi.org/10.1016/j.chemosphere.2006.03.025, 2006b.

Meskhidze, N., and Nenes, A.: Phytoplankton and Cloudiness in the Southern Ocean, Science, 314, 1419-1423, https://doi.org/10.1126/science.1131779, 2006.

Miyazaki, Y., Fu, P. Q., Kawamura, K., Mizoguchi, Y., and Yamanoi, K.: Seasonal variations of stable carbon isotopic composition and biogenic tracer compounds of water-soluble organic aerosols in a deciduous forest, Atmos. Chem. Phys., 12, 13671376, https://doi.org/10.5194/acp-12-1367-2012, 2012.

Mochida, M. and Kawamura, K.: Hygroscopic properties of levoglucosan and related organic compounds characteristic to biomass burning aerosol particles, J. Geophys. Res.-Atmos., 109, D21202, https://doi.org/10.1029/2004JD004962, 2004.

Mochida, M., Kitamori, Y., Kawamura, K., Nojiri, Y., and Suzuki, K.: Fatty acids in the marine atmosphere: Factors governing their concentrations and evaluation of organic films on sea-salt particles, J. Geophys. Res.-Atmos., 107, AAC 1-1-AAC 1-10, https://doi.org/10.1029/2001JD001278, 2002.

O'Dowd, C. D. and de Leeuw, G.: Marine aerosol production: a review of the current knowledge, Philos. T. Roy. Soc. A, 365, 1753-1774, https://doi.org/10.1098/rsta.2007.2043, 2007.

O’Dowd, C. D., Facchini, M. C., Cavalli, F., Ceburnis, D., Mircea, M., Decesari, S., Fuzzi, S., Yoon, Y. J., and Putaud, J.-P.: Biogenically driven organic contribution to marine aerosol, Nature, 431, 676-680, https://doi.org/10.1038/nature02959, 2004.

Ooki, A., Nomura, D., Nishino, S., Kikuchi, T., and Yokouchi, Y.: A global-scale map of isoprene and volatile organic iodine in surface seawater of the Arctic, Northwest Pacific, Indian, and Southern Oceans, J. Geophys. Res.-Oceans, 120, 4108-4128, https://doi.org/10.1002/2014JC010519, 2015.

Ovadnevaite, J., Ceburnis, D., Martucci, G., Bialek, J., Monahan, C., Rinaldi, M., Facchini, M. C., Berresheim, H., Worsnop, D. R., and O'Dowd, C.: Primary marine organic aerosol: A dichotomy of low hygroscopicity and high CCN activity, Geophys. Res. Lett., 38, L21806, https://doi.org/10.1029/2011GL048869, 2011 a.

Ovadnevaite, J., O’Dowd, C., Dall'Osto, M., Ceburnis, D., Worsnop, D. R., and Berresheim, H.: Detecting high contributions of primary organic matter to marine aerosol: A case study, Geophys. Res. Lett., 38, L02807, https://doi.org/10.1029/2010GL046083, 2011b.

Pacini, E.: From anther and pollen ripening to pollen presentation, Plant Syst. Evol., 222, 19-43, https://doi.org/10.1007/BF00984094, 2000.

Pashynska, V., Vermeylen, R., Vas, G., Maenhaut, W., and Claeys, M.: Development of a gas chromatographic/ion trap mass spectrometric method for the determination of levoglucosan and saccharidic compounds in atmospheric aerosols. Application to urban aerosols, J. Mass Spectrom., 37, 1249-1257, https://doi.org/10.1002/jms.391, 2002.

Pringle, K. J., Tost, H., Pozzer, A., Pöschl, U., and Lelieveld, J.: Global distribution of the effective aerosol hygroscopicity parameter for $\mathrm{CCN}$ activation, Atmos. Chem. Phys., 10, 52415255, https://doi.org/10.5194/acp-10-5241-2010, 2010.

Quinn, P. K., Bates, T. S., Schulz, K. S., Coffman, D. J., Frossard, A. A., Russell, L. M., Keene, W. C., and Kieber, D. J.: Contribution of sea surface carbon pool to organic matter enrichment in sea spray aerosol, Nat, Geosci., 7, 228-232, https://doi.org/10.1038/ngeo2092, 2014.

Ren, Y., Wang, G., Li, J., Wu, C., Cao, C., Wang, J., Zhang, L., Meng, F., and Li, H.: Seasonal variation and size distribution of biogenic secondary organic aerosols at urban and continental background sites of China, J. Environ. Sci., 71, 32-44, https://doi.org/10.1016/j.jes.2017.11.016, 2017.

Rogge, W. F., Medeiros, P. M., and Simoneit, B. R. T.: Organic marker compounds in surface soils of crop fields from the San Joaquin Valley fugitive dust characterization study, Atmos. Environ., 41, 8183-8204, https://doi.org/10.1016/j.atmosenv.2007.06.030, 2007.

Sciare, J., Favez, O., Sarda-Estève, R., Oikonomou, K., Cachier, H., and Kazan, V.: Long-term observations of carbonaceous aerosols in the Austral Ocean atmosphere: Evidence of a biogenic marine organic source, J. Geophys. Res.-Atmos., 114, D15302, https://doi.org/10.1029/2009JD011998, 2009.

Shaw, S. L., Gantt, B., and Meskhidze, N.: Production and Emissions of Marine Isoprene and Monoterpenes: A Review, Adv. Meteorol., 2010, 408696, https://doi.org/10.1155/2010/408696, 2010.

Shi, Z. B., Krom, M. D., Bonneville, S., Baker, A. R., Bristow, C., Drake, N., Mann, G., Carslaw, K., McQuaid, J. B., Jickells, T., and Benning, L. G.: Influence of chemical weathering and aging of iron oxides on the potential iron solubility of Saharan dust during simulated atmospheric processing, Global Biogeochem. Cy., 25, GB2010, https://doi.org/10.1029/2010GB003837, 2011.

Simoneit, B. R. T.: Biomass burning - a review of organic tracers for smoke from incomplete combustion, Appl. Geochem., 17, 129162, https://doi.org/10.1016/S0883-2927(01)00061-0, 2002.

Simoneit, B. R. T., Schauer, J. J., Nolte, C. G., Oros, D. R., Elias, V. O., Fraser, M. P., Rogge, W. F., and Cass, G. R.: Levoglucosan, a tracer for cellulose in biomass burning and atmospheric particles, Atmos. Environ., 33, 173-182, https://doi.org/10.1016/S13522310(98)00145-9, 1999.

Simoneit, B. R. T., Elias, V. O., Kobayashi, M., Kawamura, K., Rushdi, A. I., Medeiros, P. M., Rogge, W. F., and Didyk, B. M.: Sugars Dominant Water-Soluble Organic Compounds in Soils and Characterization as Tracers in Atmospheric Particulate Matter, Environ. Sci. Technol., 38, 59395949, https://doi.org/10.1021/es0403099, 2004a.

Simoneit, B. R. T., Kobayashi, M., Mochida, M., Kawamura, K., Lee, M., Lim, H.-J., Turpin, B. J., and Komazaki, Y.: Composition and major sources of organic compounds of aerosol particulate matter sampled during the ACE-Asia campaign, J. Geophys. Res.-Atmos., 109, D19S10, https://doi.org/10.1029/2004JD004598, 2004b.

Speranza, A., Calzoni, G. L., and Pacini, E.: Occurrence of mono- or disaccharides and polysaccharide reserves in 
mature pollen grains, Sex. Plant Reprod., 10, 110-115, https://doi.org/10.1007/s004970050076, 1997.

Srinivas, B., Sarin, M. M., and Sarma, V. V. S. S.: Atmospheric dry deposition of inorganic and organic nitrogen to the Bay of Bengal: Impact of continental outflow, Mar. Chem., 127, 170179, https://doi.org/10.1016/j.marchem.2011.09.002, 2011.

Sun, Y. L., Wang, Z. F., Fu, P. Q., Yang, T., Jiang, Q., Dong, H. B., Li, J., and Jia, J. J.: Aerosol composition, sources and processes during wintertime in Beijing, China, Atmos. Chem. Phys., 13, 4577-4592, https://doi.org/10.5194/acp-13-4577-2013, 2013.

Surratt, J. D., Murphy, S. M., Kroll, J. H., Ng, N. L., Hildebrandt, L., Sorooshian, A., Szmigielski, R., Vermeylen, R., Maenhaut, W., Claeys, M., Flagan, R. C., and Seinfeld, J. H.: Chemical Composition of Secondary Organic Aerosol Formed from the Photooxidation of Isoprene, J. Phys. Chem. A, 110, 9665-9690, https://doi.org/10.1021/jp061734m, 2006.

Szmigielski, R., Surratt, J. D., Gómez-González, Y., Van der Veken, P., Kourtchev, I., Vermeylen, R., Blockhuys, F., Jaoui, M., Kleindienst, T. E., Lewandowski, M., Offenberg, J. H., Edney, E. O., Seinfeld, J. H., Maenhaut, W., and Claeys, M.: 3-methyl1,2,3-butanetricarboxylic acid: An atmospheric tracer for terpene secondary organic aerosol, Geophys. Res. Lett., 34, L24811, https://doi.org/10.1029/2007GL031338, 2007.

Tarvainen, V., Hakola, H., Hellén, H., Bäck, J., Hari, P., and Kulmala, M.: Temperature and light dependence of the VOC emissions of Scots pine, Atmos. Chem. Phys., 5, 989-998, https://doi.org/10.5194/acp-5-989-2005, 2005.

Tervahattu, H., Hartonen, K., Kerminen, V.-M., Kupiainen, K., Aarnio, P., Koskentalo, T., Tuck, A. F., and Vaida, V.: New evidence of an organic layer on marine aerosols, J. Geophys. Res.-Atmos., 107, AAC 1-1-AAC 1-8, https://doi.org/10.1029/2000JD000282, 2002.

Uematsu, M., Hattori, H., Nakamura, T., Narita, Y., Jung, J., Matsumoto, K., Nakaguchi, Y., and Kumar, M. D.: Atmospheric transport and deposition of anthropogenic substances from the Asia to the East China Sea, Mar. Chem., 120, 108-115, https://doi.org/10.1016/j.marchem.2010.01.004, 2010.

Virkkula, A., Teinilä, K., Hillamo, R., Kerminen, V.-M., Saarikoski, S., Aurela, M., Viidanoja, J., Paatero, J., Koponen, I. K., and Kulmala, M.: Chemical composition of boundary layer aerosol over the Atlantic Ocean and at an Antarctic site, Atmos. Chem. Phys., 6, 3407-3421, https://doi.org/10.5194/acp-6-3407-2006, 2006.

Wang, G., Kawamura, K., Lee, S., Ho, K., and Cao, J.: Molecular, Seasonal, and Spatial Distributions of Organic Aerosols from Fourteen Chinese Cities, Environ. Sci. Technol., 40, 4619-4625, https://doi.org/10.1021/es060291x, 2006.

Wang, G., Chen, C., Li, J., Zhou, B., Xie, M., Hu, S., Kawamura, K., and Chen, Y.: Molecular composition and size distribution of sugars, sugar-alcohols and carboxylic acids in airborne particles during a severe urban haze event caused by wheat straw burning, Atmos. Environ., 45, 2473-2479, https://doi.org/10.1016/j.atmosenv.2011.02.045, 2011.
Xie, M., Hannigan, M. P., and Barsanti, K. C.: Gas/Particle Partitioning of 2-Methyltetrols and Levoglucosan at an Urban Site in Denver, Environ. Sci. Technol., 48, 2835-2842, https://doi.org/10.1021/es405356n, 2014.

Xu, H., Cao, J., Chow, J. C., Huang, R. J., Shen, Z., Chen, L. W. A., Ho, K. F., and Watson, J. G.: Inter-annual variability of wintertime PM2.5 chemical composition in Xi' an, China: Evidences of changing source emissions, Sci. Total Environ., 545-546, 546555, https://doi.org/10.1016/j.scitotenv.2015.12.070, 2016.

Xu, L., Guo, H., Boyd, C. M., Klein, M., Bougiatioti, A., Cerully, K. M., Hite, J. R., Isaacman-VanWertz, G., Kreisberg, N. M., Knote, C., Olson, K., Koss, A., Goldstein, A. H., Hering, S. V., de Gouw, J., Baumann, K., Lee, S.-H., Nenes, A., Weber, R. J., and $\mathrm{Ng}$, N. L.: Effects of anthropogenic emissions on aerosol formation from isoprene and monoterpenes in the southeastern United States, P. Natl. Acad. Sci. USA, 112, 37-42, https://doi.org/10.1073/pnas.1417609112, 2015.

Yang, Y., Chan, C.-y., Tao, J., Lin, M., Engling, G., Zhang, Z., Zhang, T., and Su, L.: Observation of elevated fungal tracers due to biomass burning in the Sichuan Basin at Chengdu City, China, Sci. Total Environ., 431, 68-77, https://doi.org/10.1016/j.scitotenv.2012.05.033, 2012.

Yassaa, N., Peeken, I., Zöllner, E., Bluhm, K., Arnold, S., Spracklen, D., and Williams, J.: Evidence for marine production of monoterpenes, Environ. Chem., 5, 391-401, https://doi.org/10.1071/EN08047, 2008.

Yokouchi, Y., Li, H.-J., Machida, T., Aoki, S., and Akimoto, H.: Isoprene in the marine boundary layer (southeast Asian Sea, eastern Indian Ocean, and Southern Ocean): Comparison with dimethyl sulfide and bromoform, J. Geophys. Res.-Atmos., 104, 80678076, https://doi.org/10.1029/1998JD100013, 1999.

Yttri, K. E., Dye, C., and Kiss, G.: Ambient aerosol concentrations of sugars and sugar-alcohols at four different sites in Norway, Atmos. Chem. Phys., 7, 4267-4279, https://doi.org/10.5194/acp7-4267-2007, 2007.

Yu, J., Cocker, D. R., Griffin, R. J., Flagan, R. C., and Seinfeld, J. H.: Gas-Phase Ozone Oxidation of Monoterpenes: Gaseous and Particulate Products, J. Atmos. Chem., 34, $207-$ 258, https://doi.org/10.1023/a:1006254930583, 1999.

Zheng, M., Yan, C., Wang, S., He, K., and Zhang, Y.: Understanding PM2. 5 Sources in China: Challenges and Perspectives, Nat. Sci. Rev., 4, 801-803, https://doi.org/10.1093/nsr/nwx129, 2017.

Zhou, M. Y., Yang, S. J., Parungo, F. P., and Harris, J. M.: Chemistry of marine aerosols over the western Pacific Ocean, J. Geophys. Res.-Atmos., 95, 1779-1787, https://doi.org/10.1029/JD095iD02p01779, 1990.

Zhu, C., Kawamura, K., and Kunwar, B.: Effect of biomass burning over the western North Pacific Rim: wintertime maxima of anhydrosugars in ambient aerosols from Okinawa, Atmos. Chem. Phys., 15, 1959-1973, https://doi.org/10.5194/acp-151959-2015, 2015.

Zhu, C., Kawamura, K., and Fu, P.: Seasonal variations of biogenic secondary organic aerosol tracers in Cape Hedo, Okinawa, Atmos. Environ., 130, 113-119, https://doi.org/10.1016/j.atmosenv.2015.08.069, 2016. 